The STOVIA, dokter djawa 1875-1915

In 1875 the doctor training programme was reformed, and this had consequences for the position of the graduates on the medical market. In 1902 further revisions were introduced, leading to a change in the name of the school and of the graduates: School ter Opleiding van Inlandsche Geneeskundigen became the School tot Opleiding van Inlandsche Artsen (STOVIA, School for the Education of Native Doctors), and dokter djawa became Inlandsche arts (native doctor). Still later in 1913, when all races were admitted the title was changed into Indische arts (Indies doctor). In this chapter the term dokter djawa is often used for all alumni: the majority used this title, which was still in common use until well into the twentieth century (Lauw 1987:146).

TRAINING PROGRAMME

In 1875 the training programme was radically modified: its duration was extended from three to seven years, with two years of preparatory, fundamental education and five years of medical tuition, and the number of students was increased from 50 to 100 . The language of instruction became Dutch. ${ }^{1}$

\title{
DUTCH
}

The introduction of Dutch instead of Malay as the language of instruction took a lot of effort; many methods were tried to teach the students the language. First, in 1878 the minimum age for admission was lowered 1 Reglement voor de school tot opleiding van Inlandsche geneeskundigen, GB 24-11-1875 no. 7, Ind. Stb. 1875 no. 265. 
because younger students would find it easier to learn Dutch. ${ }^{2}$ When this produced insufficient results, the preparation phase was extended by a year in 1881 (Ind. Stb. 1881 no. 160). In 1885 the number of hours of Dutch in the preparation phase was increased ( $K V$ 1885:115); but this measure was cast aside after just one year because of poor results clearly, they were rather impatient ( $K V$ 1887:108). Instead, the students were now required to speak Dutch outside school hours. Despite severe punishment for contravening the rule, little benefit was seen in practice (De Waart 1926a:16). The teachers produced a range of textbooks in Dutch, a handbook for pathology plus two sections on special pathology and therapy, almost 1500 pages in total, and that was just for one subject. ${ }^{3}$ The level of the training programme was clearly being raised. The results were terrible in the first years after 1875: of the students admitted between 1876 and 1880, only 20\% made it to the medical section (De Waart 1926a:19). Great efforts had to be made, therefore, to improve this situation.

In 1879 the regional administrators were expressly requested to recruit candidates who could read, write and speak Dutch. ${ }^{4}$ When it became clear that they were also the better students, it was decided in 1889 only to admit students who had completed the middle class of the European primary school or attended one of the schools for native heads. ${ }^{5}$ Only fee-paying native children were admitted to the European primary school, ${ }^{6}$ which restricted this education to a small group. The intake to the doctor's school consequently decreased. To compensate for this, a maximum of eight boys aged 6-8 years were admitted free of charge to the European primary school in 1891 on the condition that they would be trained as a dokter djawa. At first, this condition applied

\footnotetext{
2 It was 14-18 years, Reglement voor de school tot opleiding van Inlandsche geneeskundigen art. 8, GB 24-111875 no. 7, Ind. Stb. 1875 no. 265. It became 12-14 years, GB 11-10-1878 no. 8, Ind. Stb. 1878 no. 262. In 1881 the minimum age for the preparatory phase was 12-16 years and for the medical section 16-20 years, Ind. Stb. 1881 no. 160. In 1902 the minimum age became 12-17 years, see art. 9a Regulation 1902 Ind. Stb. 1902 no. 443.

$3 \quad$ A handbook numbering 190 pages (De Freytag 1882) and a two-part textbook of 566 and 710 pages, respectively (Van der Elst 1883).

4 Circular director of Education, Religion and Industry 22 -8-1879 no. 10435, Bïblad 3436.

5 Circular director of Education, Religion and Industry to administrators in and outside Java and Madura 9-10-1889 no. 10305, Bïblad 4530.

$6 \quad$ KV 1890:98; exceptions were made for children of the teaching staff and for children of lowerranking native soldiers from the residencies of Manado, Ambon, Ternate and Timor if they were Christian and located outside these residencies.
} 
only for the Outer Islands (except the Moluccas); ${ }^{7}$ in 1896 the trial was extended to Java and Madura. ${ }^{8}$ Every boy who took advantage of this opportunity thus chose his career at the age of six.

\section{MORE PRACTICE}

To give the students more practice, outpatient clinics were opened, one for surgery and eye diseases in 1890 and one for internal diseases a year later (KV 1890:123; KV 1891:133).

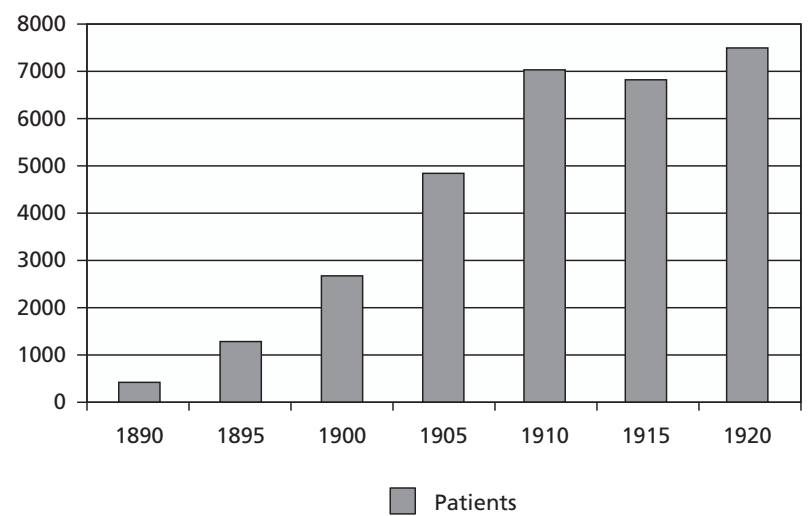

Graph 6.1. Number of patients in the outpatient clinics of STOVIA, 1890-1920 (De Waart 1926b:365)

The graph shows that the number of patients in the outpatient clinics increased over time. The 95 students in the medical section around 1910 must have had their hands full with the 7000 patients. The director of the school realised that more personnel were needed, but given the great deficiency of native doctors, they decided not to ask for more assistantteachers (Faarlijksch verslag STOVIA 1903:8).

$7 \quad$ GB 28-8-1891 no. 11, KV 1892:97 note 2. The European primary school was attended here by even fewer natives than on Java and the Moluccas.

8 For a maximum of 30 students, GB 15-1-1896 no. 8, KV 1896:105. In 1900 this number was increased to a maximum of 80 (60 for Java and Madura, 20 for the Outer Islands), GB 26-6-1900 no. 10, Bïblad 5508. The editor of Het Nieuws van den Dag voor Nederlandsch-Indï̈ (19-1-1901, p 3) brought this circular to the attention of its readers.

165 


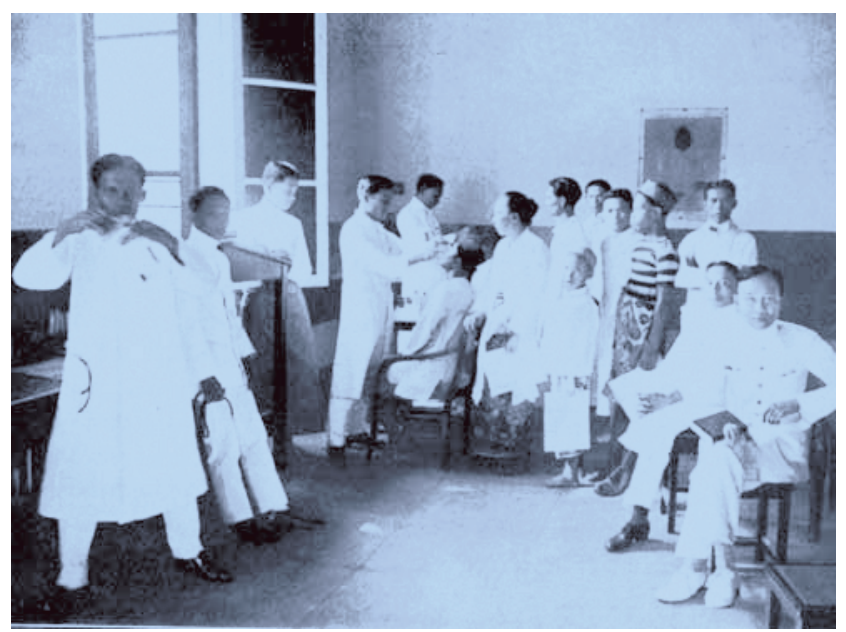

Outpatient eye clinic around 1920 (De Waart 1926b:238)

Furthermore, it was decided that poor natives and Chinese could stay 'a while for observation in the interests of educating the apprentices'; they were nursed free of charge in the 4th class of the military hospital in Jakarta. ${ }^{9}$ At the beginning there were only two beds; in 1899 there were 10 (De Waart 1926a:20). A request to increase this number to 15 was denied in 1902. ${ }^{10}$ To provide the students with sufficient practical experience, it was agreed that they would visit the municipal hospital twice a week (De Waart 1926a:37). In 1907 the number of free beds was increased to $40 .^{11}$

\section{FURTHER IMPROVEMENTS}

Around 1900 the Dutch government changed its colonial policy. With the queen's speech of 1901, the so-called ethical policy made its entrance. For the first time the government declared that it felt responsible for the welfare and prosperity of the population. Part of this was a tentative form of health care for the natives, which led to an increase in the need 


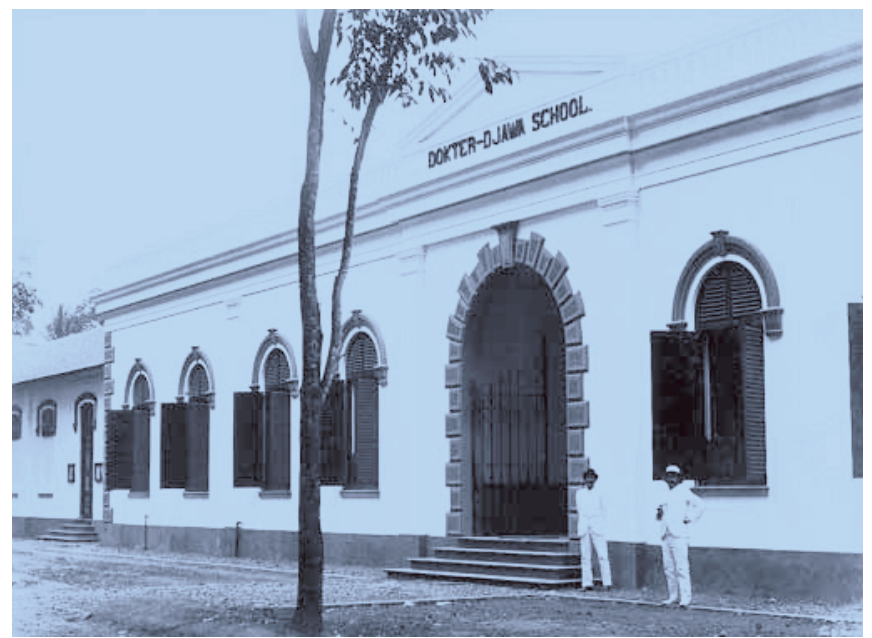

The new school building (photo collection KITLV 35810)

for doctors (European and native). New investments were made in the dokter djawa training programme. ${ }^{12}$ The preparatory phase was extended again, now to three years, and the medical section to six years. ${ }^{13}$ The additional year was needed for the new subjects of obstetrics and forensic medicine ( $K V$ 1899:119). An admissions exam became mandatory, which could be taken at all European primary schools in the archipelago. ${ }^{14}$ The dokter djawa school, now called STOVIA, was given its own director and a deputy director, both of whom were teachers. The maximum number of students was doubled from 100 to $200 .{ }^{15}$ A new school building was built with a generous gift from three rich Deliplanters, friends of the minister of Colonies, J.T. Cremer, a former Deliplanter. ${ }^{16}$

12 Director H.F. Roll formulated the improvements in 1898, Roll 1909:4. According to Van Niel 1960:51 stimulation for the improvement had come from the Deliplanters as the maintenance of the labour force (contract labourers mostly) was difficult; therefore, they placed great emphasis on the health of their employees. This claim can be neither supported nor refuted.

13 The preparatory phase was shortened to 2 years again in 1890, De Waart 1926a:19.

14 Art. 10 Regulation 1902, Ind. Stb. 1902 no. 443.

15 GB 25-1-1900 no. 19, KV 1900:107.

16 Originally, they provided $f 100,000$ for the construction of a midwives' school. When the Indies government indicated that improvement of general medical aid took priority and thus it preferred an expansion of the dokter djawa school, they increased the sum to $f 170,000$, Minister of Colonies Cremer when preparing the budget for Netherlands Indies for 1899, Handelingen TK 1898-89, meeting of 24-111898, 231. 


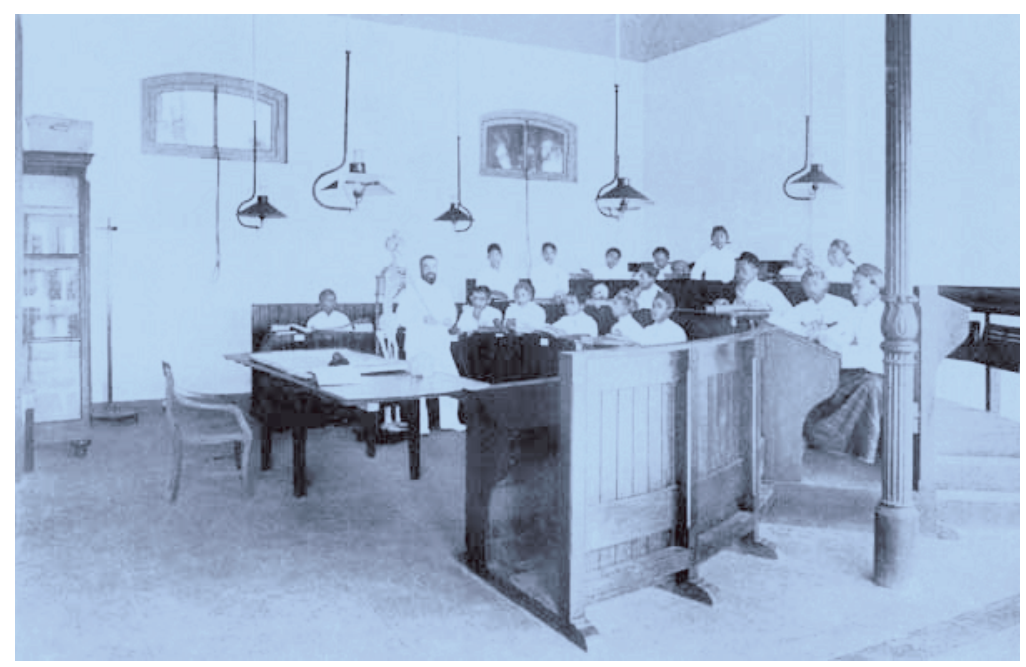

Director H.F. Roll with a class of students (photo collection KITLV 35813)

The introduction of obstetrics as a subject did not go smoothly. The new school building meant enough space was left in the military hospital for a maternity clinic, particularly for Ambonese soldiers' wives/concubines (De Waart 1926a:26-7). An Ambonese midwife was appointed to the school, who supervised the oldest students assisting at deliveries of soldiers' wives/concubines in the military hospital and of women in the kampong (Boerma 1926:224). This free supervision was not restricted to the delivery; the students continued to visit the new mother for nine days afterwards (Aboe Bakar 1926:329). In addition, the mothers received a bonus of $f 7.50$ for their willingness to allow the students to assist (Boerma 1926:224; Aboe Bakar 1926:332). Midwifery was the only subject for which the students entered the kampong. The new subject increased the graduates' competence, and they were given the title of Inlandsche arts. Older dokter djawa could supplement their training in obstetrics by taking that part of the exam, and then they were also awarded the title of Inlandsche arts. ${ }^{17}$ 


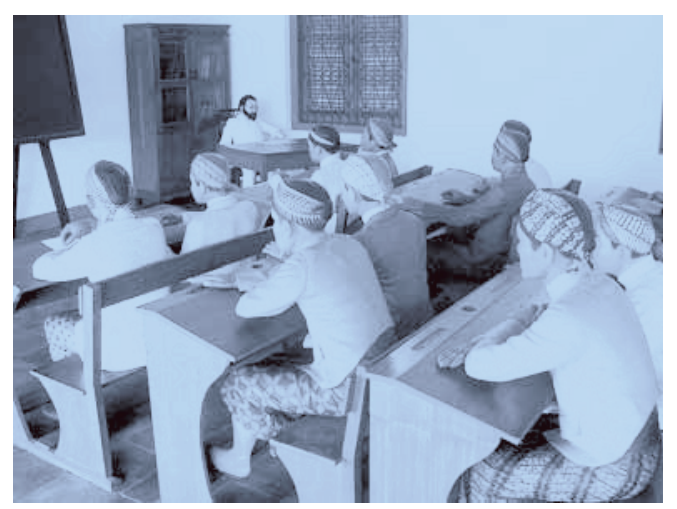

A full-sized replica of photo on page 168 was built as a diorama and can be viewed in the former school building, now a museum (photo J.H. Peters)

\section{STUDENTS}

The prospective student had to provide proof of good conduct, demonstrate that he had been vaccinated against smallpox and was not married. Exceptions to the last rule were only made for those who could provide for their wives outside the school. ${ }^{18}$

\section{CLOTHING}

The students' clothing revealed which part of the archipelago they came from. For example, Javanese students wore a traditional head covering, kain (wrap), black jersey open jacket with a stiff collar and black tie.

Outside the school grounds all of the students wore numbered caps with the symbol of Aesculapius's staff, and in the last three years of the course, a golden chin strap as well (Goeteng Taroenadibrata 1926:281). Leaving the grounds without a head covering was punished. ${ }^{19}$ Some students were proud of their 'cap with the insignia in the form of a yellow snake wound around a flowering vine' (Pramoedya Ananta Toer 1988:32); others detested it because it made them recognisable everywhere they went. The clothing of the students of OSVIA, the school for

\footnotetext{
18 Regulation 1899 art. 8, De Freytag 1899:53.

19 The fine was 50 cents according to Goeteng Taroenadibrata (1926:281). Two days of confinement according to Samallo (1926:290).
}

169 


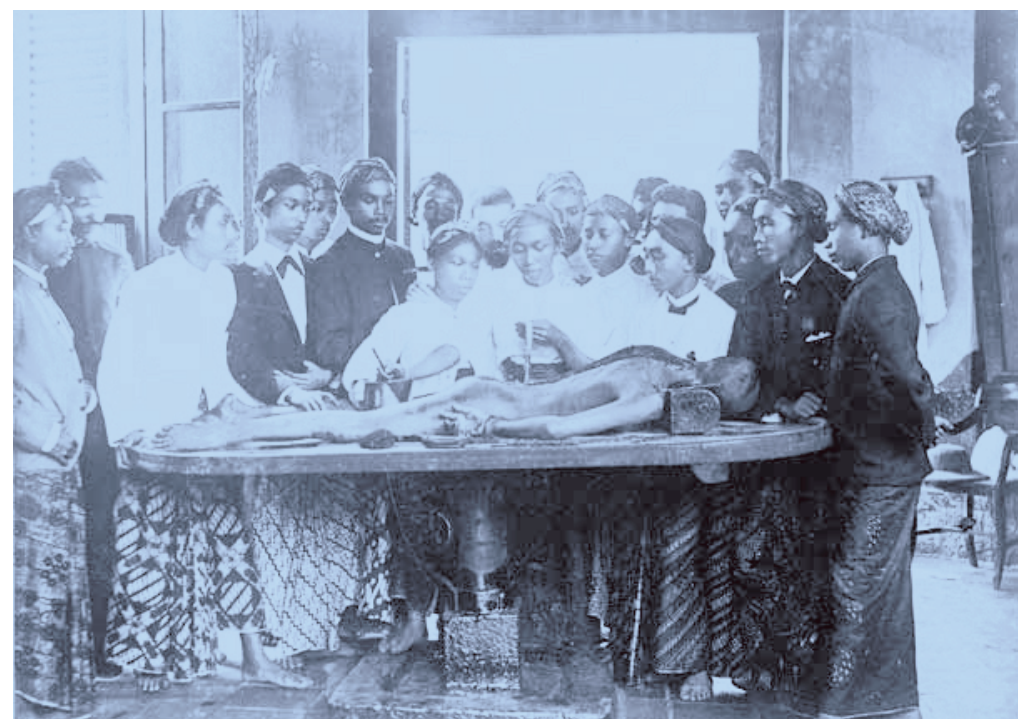

Anatomical lesson. In the photo it is evident that the students' clothing varied according to their regions of origin and that they were barefoot. (photo collection KIT 10002345)

native officials, was identical to that of STOVIA. ${ }^{20}$ This was probably a deliberate strategy by the government: by forcing the students to wear native clothing, they would not become alienated from the local population. Raden Mas Tirto Adhie Soerjo experienced the obligation to wear the traditional Javanese dress without shoes as humiliating. ${ }^{21}$

$20 \quad$ As seen in the photo in Van den Doel 1996:169.

${ }^{21}$ He did not finish the school, but became a journalist, Pramoedya Ananta Toer 1995. According to Van Niel (1984:55) this was more injurious because at the European primary school (since 1889 the required preparatory education for STOVIA), they were allowed to wear European clothing. In the memoirs of Margono Djojohadikusumo (1970:18) this was not the case. Until 1908 native soldiers - except Ambonese and Menadonese - went barefoot, Willems 1997:66. In 1939 A. de Waart, then chair of the medical faculty, in a meeting organised by a student society, glossed over the earlier obligation that the students went barefoot, Wertheim and Wertheim-Gijse Weenink 1991:167. 


\section{THE GRADUATES AND THEIR WORKING CONDITIONS}

The government was following a clear line by investing in the training programme - 'everything' was aimed at producing more and better trained dokter djawa; but in terms of the working conditions, the policy was much less obvious.

\section{SALARY}

In 1875 the starting salary was increased from $f 30$ to $f 50$ per month with four raises of $f 10$ at 5 -year intervals of faithful service and devotion to duty. ${ }^{22}$ The maximum monthly salary after 20 years of service amounted to $f 90$. This new salary was much lower than that for a teacher, who received a monthly salary of $f 75$, with a raise every three years of $f 15$ to a maximum of $f 150 .{ }^{23}$ It is unclear why the government permitted such a large financial inequality between a dokter djawa and a teacher now that the dokter djawa training programme had been improved: the starting salary of a teacher was $50 \%$ higher than that of a dokter djawa and the maximum salary, $67 \%$.

In 1899 the salary of the dokter djawa was raised. Perhaps the then government advisor C. Snouck Hurgronje had a positive influence on this matter. In March 1898 he wrote to the director of Education, Religion and Industry: 'In development these native doctors greatly exceed that of the majority of native officials; their rank remains the lowest, independent of years of service and merit, and their income remains far below the criteria imposed on them by association in the priyayi's world. ${ }^{24} \mathrm{He}$ advised significantly increasing the salary of the dokter djawa. ${ }^{25}$ This came to pass: the starting salary became $f 70$ with four 3 -yearly raises of $f 20$ to a maximum of $f 150 .{ }^{26}$ The explanatory memorandum to the Indies budget for 1899 showed that the government had realised that the financial position of the dokter djawa compared unfavourably with that of other native officials, who had undergone a shorter and simpler training

\footnotetext{
22 GB 24-11-1875 no. 7, Ind. Stb. 1875 no. 264.

23 Art. 2, GB 6-2-1878 no. 5, Ind. Stb. 1878 no. 60.

${ }^{24}$ Letter to director of Education, Religion and Industry 21-3-1898, Gobée and Adriaanse 1956:1040.

${ }_{25}$ Letter to director of Education, Religion and Industry 21-3-1898, Gobée and Adriaanse 1956:1041.

$26 \quad$ Ned. Stb. 1899 no. 125; Ind. Stb. 1899 no. 38.
} 
programme. ${ }^{27}$ In 1910 the starting salary became $f 150$ per month with four 3-yearly raises of $f 25$ to a maximum of $f 250$ (De Waart 1926a:43).

\begin{tabular}{|l|c|c|c|c|}
\hline & Starting salary & Raise & Interval & Maximum salary \\
\hline 1875 & 50 & $4 \times 10$ & After 5 years & 90 after 20 years \\
\hline 1899 & 70 & $4 \times 20$ & After 3 years & 150 after 12 years \\
\hline 1910 & 150 & $4 \times 25$ & After 3 years & 250 after 12 years \\
\hline
\end{tabular}

Table 6.1. The salary of a dokter djawa, 1875-1910

Despite these raises the dokter djawa justly complained about their salary. It contrasted starkly not only with that of a teacher, but also with other officials such as the assistant-translator Kartawinata. His starting salary was $f 125$ per month around 1875, much more than the $f 90$ for a dokter djawa at the end of his career (Van den Berge 1998:100-1). In a lecture for the Indisch Genootschap (Indies Society) in The Hague, the Inlandsche arts W.K. Tehupeiory (1908:115-6) compared the situation of the dokter djawa around 1900 with that of native officials of an equivalent rank such as an assistant-district head; his starting salary was $f 120$-150 per month versus $f 70$ for a dokter djawa. Native veterinarians started with $f 75$ after a study lasting only three years, and their maximum was also $f 150$. Tehupeiory's findings were confirmed by the municipal physician in Semarang, W.Th. de Vogel; according to him the maximum salary of a dokter djawa was lower than that of all other native officials. ${ }^{28}$

\section{TRANSFER}

Dokter djawa were often transferred. The future nationalist Soetomo worked between 1911 and 1919 at seven different postings spread all over Java and East and South Sumatra (Van der Veur 1987:xxiv). It is strange that the expense associated with these transfers, for example for the administrative processing, did not stimulate the usually frugal government to let the physicians work longer at one post. In addition, they sometimes

${ }_{27}$ Handelingen TK 1898-9, part 3, appendix B no. 6, 19.

${ }_{28}$ W.K. Tehupeiory 1908:210. De Vogel was on leave in the Netherlands at that time and attended the meeting at which Tehupeiory spoke, and De Vogel raised this matter during the discussion afterwards. 
ended up in an area where they did not speak the local language. The many transfers did not promote a relationship of trust between the dokter djawa and his patients, and presented the dokter djawa with financial problems. The journey from one post to another often took several days. Along the way he had to eat and sleep. The daily allowance, traditionally $f$ l, was too little to cover those needs. For example, a native doctor was transferred from Surabaya to Dobo (Ambon). Halfway there, he had to wait for 14 days for a ship to take him to his new post. The hotel cost $f 5$ per day; just to cover the hotel bill, he had to pay $f 56$ from his own money (Augustin 1914:25). It was aggravating that other native officials received higher daily allowances. In later years a dokter djawa would often claim to be ill after receiving a notice that he was to be transferred, possibly a form of sabotage. It apparently happened so often that in 1916 the head of the Civil Medical Service was authorised in the interest of the Service to have the sufferers examined by a medical commission. ${ }^{29}$

\section{STATUS SYMBOLS}

Since 1870 the dokter djawa wore an official uniform conforming to the rank of mantri (Bijblad 2308); since 1882 they were entitled to carry a payung, equivalent to the rank of a native teacher first class (B̈̈blad 3861). The official uniform belonged to a lower rank than the payung. At the end of 1892 this incongruity was abolished: both the official uniform and the payung of the dokter djawa were made equivalent to that of a teacher first class. The government decided on this 'with the aim to harmonise the social standing of the dokter djawa better with the criteria they have to meet, in terms of civilization'. ${ }^{30}$

In 1901 the government took an additional measure to improve the financial position of the dokter djawa 'to some extent'; the phrase 'to some extent' in the Colonial Report indicates that the government realised that the measure was inadequate. The dokter djawa was finally classed under the native officials who had to keep carriages for their work, for which they were partially exempt from the tax on carriages for natives. ${ }^{31}$ Vaccinators had been classified like this since 1887 (Ind. Stb. 1887 no. 121). From 1903 graduates were given the rank of assistant-district

29 GB 17-1-1916 no.11, Bïblad 8454.

3o Ind. Stb. 1892 no. 251, KV 1893:130.

$31 \quad$ Ind. Stb. 1901 no. 231; other native officials obtained this right earlier, see Ind. Stb. 1885 no. 25. 


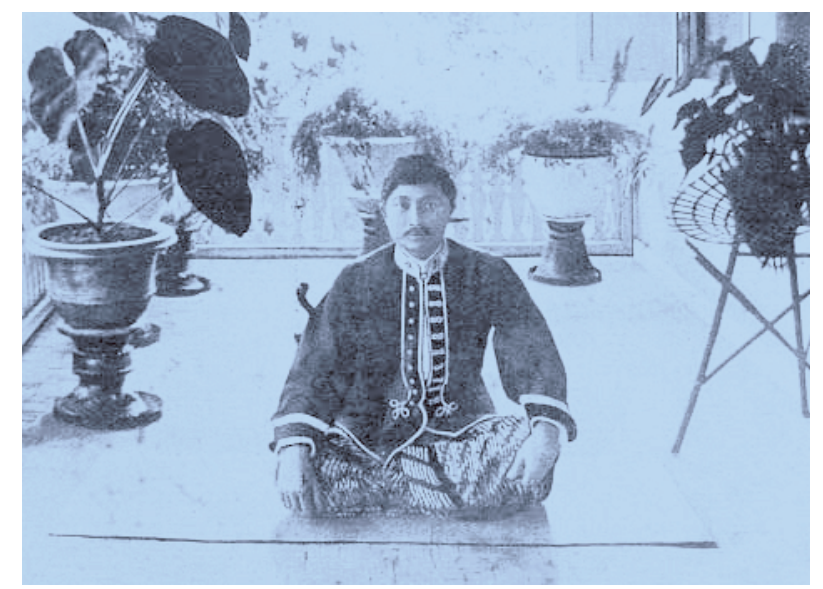

Raden Goeteng Taroenadibrata in the official uniform around 1900 (De Waart 1926b:282)

head, and of district head after reaching their maximum salary (Ind. Stb. 1903 no. 369). After the salary raise in 1910, this stipulation was upheld (Augustin 1914:14).

It remains a mystery why the government did not want to make the dokter djawa equivalent to other native officials such as vaccinators and teachers, either in salary or in status symbols, although government statements suggest it was fully aware of the inequality.

\section{THE GRADUATES AND THEIR TASKS}

After the training programme had been significantly improved in 1875 , the graduates could be trusted with more tasks. From 1883 their medicine case contained more instruments than before and more modern ones, including a stethoscope, a thermometer and dental instruments (Ind. Stb. 1883 no. 232). They were increasingly employed as primary care doctors. Health officer W. Pauw (1898:788) stated briefly and to the point, 'Now a dokter djawa is, so to speak, a civil physician in miniature'.

In 1874, it had already been decided that to aid the graduates' practical development, they would spend the first year after their final exam 
working in a municipal hospital in one of the three main towns on Java. ${ }^{32}$ In 1911, after his final exam, P.L. Augustin (1914:7-9) started working with two classmates in the municipal hospital in Surabaya. In the mornings they spent an hour in the outpatient clinic; next they each treated 70-80 patients on various wards. Then they moved on to surgery: simple operations they carried out themselves; they assisted a specialist with difficult ones. After lunch they sometimes had to travel to a neighbourhood located more than an hour away, at the request of the police or the district head to examine someone who possibly had a contagious disease. They took turns at 24-hour supervisory duty, during which they carried out autopsies for the court and examined suspicious cases. Sometimes they had to vaccinate 500-600 people in a kampong against cholera, which put additional pressure on those remaining behind in the hospital. There was no time for private patients. When a shortage of native doctors developed, they were rapidly transferred to work independently or to assist European physicians. Augustin was sent after just one and a half months to Merauke (New Guinea).

\section{A 'NORMAL' PRACTICE}

In his lecture for the Indies Society described above, W.K. Tehupeiory presented a detailed image of the tasks of the dokter djawa at the turn of the twentieth century. In his post at Medan (Sumatra's East Coast), he treated the patients in the men's hospital, on average 70 men, but at the time of an expedition sometimes up to 100, and around 20 women in the women's hospital. In the men's hospital he held an outpatient clinic every morning, which was visited daily by about 20 patients in his estimation. According to the annual report on the Civil Medical Service, however, a total of 256 patients was seen in the entire year of 1902 (Haga 1903:760). Furthermore, he was responsible for the leper institute that housed an average of 20 lepers. In the prison he examined a dozen people daily, but this number could rise to 40 when prisoners were brought in from an outpost. In addition, he examined the prostitutes: about 40 Japanese and Klingalese on Tuesday and Saturday and 100 Chinese on Thursday. Furthermore, he was charged with forensic investigations. He 
had to supply the court with written statements, which took a great deal of his time as there were three days of sessions every week. Once a week he held an outpatient clinic in a place about five $\mathrm{km}$ from Medan. This was his regular job from which he earned $f 70$ per month. For the treatment of about 60 Chinese in the hospital maintained by the Chinese, he received a monthly allowance of $f 50$ (W.K. Tehupeiory 1908:111).

During an epidemic, he was expected to disinfect contaminated houses and public buildings along with his normal work and to visit villages sometimes located over $30 \mathrm{~km}$ from Medan. As if that were not enough, during his two years in Medan he covered for the dokter djawa in Labuan-Deli for five months and one month for a colleague in LubukPakam. Both places were located one hour by train from Medan (W.K. Tehupeiory 1908:111-2). This was quite a heavy load, even for a young, hard-working doctor like W.K. Tehupeiory. The number of outpatient visitors was probably exaggerated in order to impress his imposing audience and in the hope of contributing to an improvement in the situation of the native doctors. Tehupeiory did not even mention all the documentation a government physician had to prepare, such as writing reports and answering queries.

Native doctors were allowed to establish a private practice alongside their government post, just like their European colleagues. That was not easy to accomplish in reality, however. According to Snouck Hurgronje and also Tehupeiory, setting up a lucrative private practice was only possible in places where rich Chinese lived. ${ }^{33}$ Tehupeiory (1908:115) described rather enviously that he knew of several dokter djawa on Sumatra's east coast who daily treated 50 to 100 poor Chinese free of charge in the outpatient clinic and severely ill Chinese women at home, who apparently could not make it to the outpatient clinic. These dokter djawa could afford to do this because of the generous payments from other Chinese. They were financially independent and did not work in government service. Augustin (1914:19) recounted that a few native doctors managed to earn 60-70 guilders per month with a private practice alongside their regular tasks. The colonial government set the fees: dokter djawa were only allowed to charge their fellow countrymen one guilder per visit. This fee, set in 1874, was still unchanged 30 years later. ${ }^{34}$

\footnotetext{
33 Letter to director of Education, Religion and Industry 21-3-1898, Gobée and Adriaanse 1956:1040.

34 Education, Religion and Industry Circular 5-10-1874 no. 10337, De Freytag 1899:62.
} 


\section{NEW TASKS}

Near the close of the nineteenth century, the many infrastructural projects that the government implemented produced a new field of work for European and native doctors. The Agrarian Law of 1870 led to an increase in private initiatives, which produced economic expansion and then the construction of railways, ports and roads (Joop de Jong 2000:292-3). European physicians and dokter djawa were temporarily employed to care for the personnel who worked on the building of the roads and canals, railways and telegraph lines. In addition, doctors were sought to care for the employees of government enterprises such as the tin mines on Bangka.

Medics were also needed on the military expeditions as part of the 'consolidation' of the colonial empire in the Indies. First of all, in the protracted war in Aceh, four dokter djawa had been stationed there since the end of 1876 (KV 1877:133). The two dokter djawa associated with the school as assistant-teachers went along on the campaign to Lombok in 1894-1895 (KV 1895:150). In addition, doctors had to accompany many scientific expeditions around the turn of the century. For example, the Inlandsche arts J.E. Tehupeiory, the older brother of W.K. Tehupeiory, went on an expedition to Kalimantan in 1902; he wrote the book Onder de Dajaks in Centraal Borneo (Among the Dayak in Central Kalimantan, 1906) about his journey. Another new aspect was accompanying pilgrims to Mecca. A doctor had to sail on ships with more than 200 passengers. ${ }^{35}$ One of those supervising a journey to Mecca in 1887 was I. Groneman, the sultan of Yogyakarta's personal physician (Buddingh' 1989:7). Advisor for Native Affairs Snouck Hurgronje proposed in 1888 making a skilled dokter djawa available for the consul in Jeddah, who as a Muslim would have free access to Mecca and would win trust in many circles through his work. It took 30 years before the first native doctor was appointed. ${ }^{36}$

Individuals were assigned to missionary hospitals, such as Ismael in Mojowarno (Nortier 1939:259). Soetomo worked in 1912 in the missionary hospital in Blora (Pramoedya Ananta Toer 1988:26). He was not a Christian, although generally Christian dokter djawa were sent to the mis-

\footnotetext{
35 Ordinance GG 7-5-1902, Ind. Stb. 1902 no. 199.

$3^{6} \quad$ NA, archive of consulate in Jeddah, 1872-1930, access number 2.05.53, found via www.moranmicropublications.nl.
} 


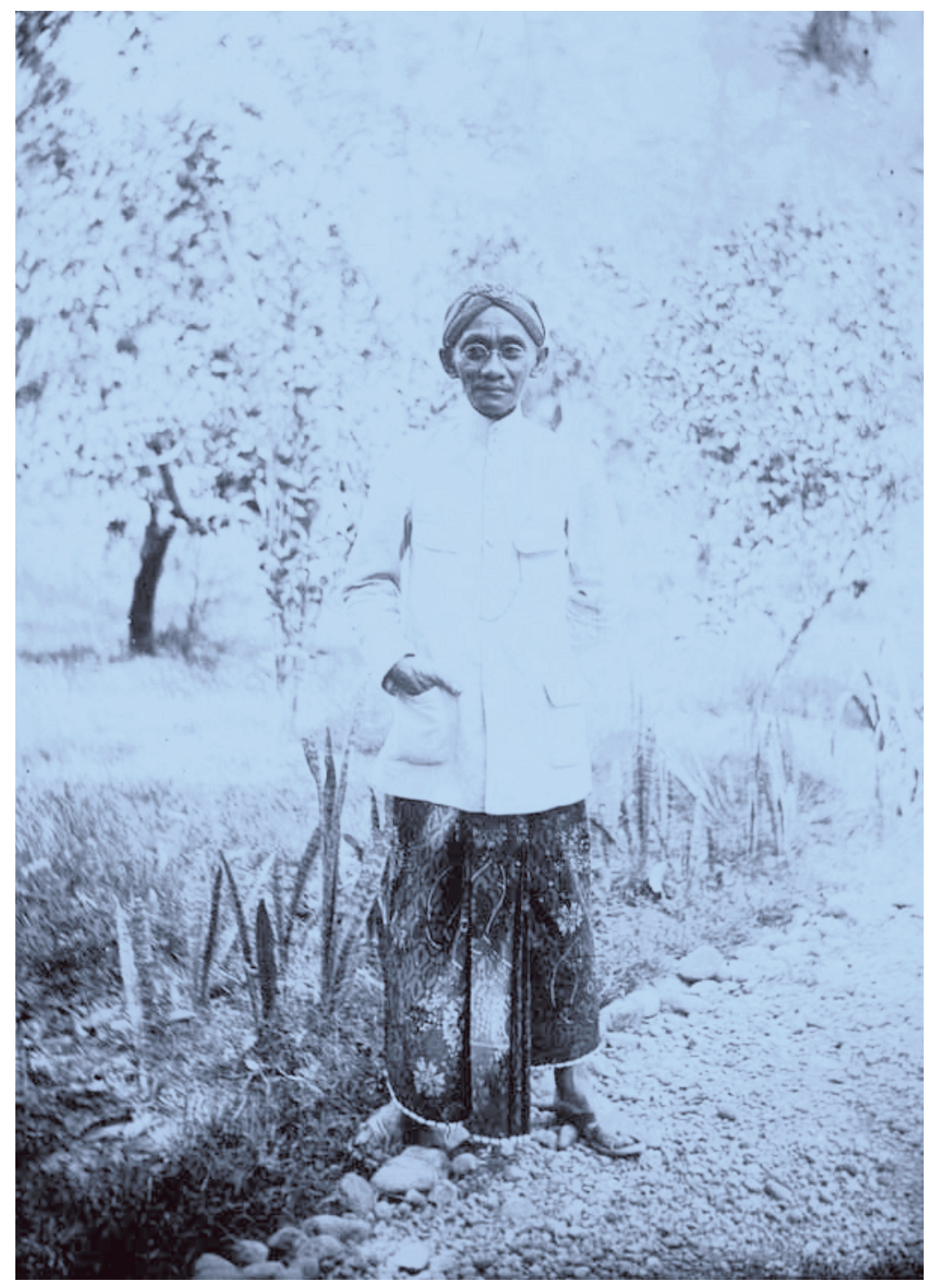

Dokter djawa Ismael (photo collection KIT 10018625) 
sionary clinics. They remained in government service and were seconded to a missionary hospital.

\section{INTERMEDIARY}

In this period the government and the European physicians increasingly involved the dokter djawa as an intermediary: their training programme and background sometimes allowed them to fulfil a bridging role between the population and Western medicine. The editors of the Tijdschrift voor Inlandsche Geneeskundigen often used them as informants. ${ }^{37}$ For example, the editor and also teacher at the school, A. van der Scheer (1893:56), asked them to collect data about opium use:

You, dokter djawa, given the nature of your employment are best suited to investigate the influence of smoking opium. We hope that you would be willing to commit your observations to paper, make notes showing the nature of withdrawal symptoms that you observed in your patients, and if possible describe the pathological changes that you find when conducting autopsies of addicts.

The Civil Medical Service inspector, A.G. Vorderman, was an expert on indigenous remedies. He still asked for help from the dokter djawa when trying to catalogue all of the tricks used by native criminals when preparing poison to get rid of people without being suspected. According to Vorderman (1893:81-3) the dokter djawa would learn about these ruses sooner than European physicians because they understood the language and the customs better. Several years later, in 1897, the regional administrators in the Indies were asked by the director of Education, Religion and Industry to collect the poisons used by the natives on behalf of the students being trained in the Pharmaceutical Laboratory in Utrecht for the military pharmaceutical service in the Indies. The director pointed out that it could be very fruitful to use the services of dokter djawa. ${ }^{38}$

The director of the vaccine institute and the Pasteur institute,

\footnotetext{
37 The periodical was established in 1893. The editorial board consisted of the director and/or a teacher from the school. The contents kept the graduates informed about the latest developments through articles from teachers and actual case studies from graduates. Authors were paid a fee.

$3^{8} \quad$ Circular 17-3-1897 no. 3899, Greshoff 1902:9-11. The appeal resulted in a flood of material and data, which were processed by M. Greshoff, and published in Indies vergiftrapporten [Poisoning reports from the Indies], The Hague:Van Kleef, 1899-1900 (reissued in 1902 and 1914).
} 
L.J. Eilerts de Haan, was very interested in massage, which had little to do with his position. ${ }^{39}$ In 1893 he presented two patients whom he had treated with massage at a meeting of the Vereeniging tot Bevordering der Geneeskundige Wetenschappen in Nederlandsch-Indië. He was pleased with the results achieved and curious about other people's experiences. ${ }^{40}$ In the same year he published in the Tijdschrift voor Inlandsche Geneeskundigen a rather technical article about massage with precise instructions that culminated with an appeal to the dokter djawa:

In general, the manner in which the natives apply massage probably differs quite a bit from the method described here, but little has been written about it so far. It would be important for the dokter djawa, who come into contact frequently with the population, to investigate in detail how massage is applied in the different regions of the Netherlands Indies. Perhaps in this field, like in many others, a lot can be learned from the experience of non-medical personnel. I shall close with a request to you all to ascertain which diseases of men and animals the natives treat with the application of massage and what methods they use, and to communicate your findings to the editor of this periodical. The smallest detail is of interest, many small pieces form a large whole. (Eilerts de Haan 1893:43.)

Regarding sensitive topics in the indigenous society - as in the European - like abortion, menstruation and circumcision, it seemed logical that interested Europeans would turn to the dokter djawa instead of embarrassing the natives. The previously mentioned editor Van der Scheer asked the dokter djawa whether they would try 'to learn about some indigenous abortifacients from dukun, as in the European medicine no one has yet succeeded in finding an abortifacient that definitely works in all cases' (Asharie 1896:31-2). This quotation reflects an equal relation between the European and the indigenous medicine: the European medicine did not know of a safe abortifacient, but perhaps the indigenous medicine and the often disparaged dukun did.

Sometimes little tasks were involved, for example the dokter djawa were requested to collect rice samples for research into the cause of

39 Later, definitely from 1897 onwards, he worked in an institute for massage and mechanotherapy, affiliated to the military hospital in Jakarta, Eilerts de Haan 1898:288.

$4^{\circ} \quad$ Notulen Geneeskundige Vereeniging 1894:113. 
beriberi. ${ }^{41}$ This seems a simple assignment in a land where rice is the primary staple, but by involving the dokter djawa who knew what these samples were for, the chance that they would be collected carefully was greatly increased. A similar request concerned delivering an orang-utan for an investigation of the cause of syphilis. At the turn of the twentieth century, the German scholar A. Neisser resided in Jakarta for several years, conducting research on syphilis. ${ }^{42}$ The editor of the Tijdschrift voor Inlandsche Geneeskundigen, G.W. Kiewiet de Jonge, issued an urgent request to the dokter djawa to assist science by ensuring that Neisser obtained an orang-utan (Kiewiet de Jonge 1905:160-4). The dokter djawa were asked rather than a random native because they knew that the apes were needed for scientific research.

In the case studies described, there was an evident gap between the indigenous society and the European physicians, who rarely came into contact with natives given the composition of their patient population. In addition, they generally spoke Malay poorly, and Javanese or Sundanese not at all. The cultural and social barriers between the two groups were large. In an attempt to bridge them, the Europeans called on the dokter djawa to act as an intermediary.

Sometimes this process went a step further, and the dokter djawa were employed by the government and its officials to support the Dutch rule. An example was provided by A.J.N. Engelenberg, controleur on Lombok from 1894 to 1900, The island had just been brought under direct administration of the Netherlands after the greatest defeat in the history of the Indies army, known as the 'Treason of Lombok' (Vanvugt 1996:155). Engelenberg (1926:274) described how the people suffered under the long-lasting rebellion of the Sasaks, the original inhabitants of Lombok, against the Balinese administration (and under the consequences of the government's military expedition, although Engelenberg did not mention the latter aspect). Hunger was prevalent, and all kinds of diseases raged among the inhabitants, who did not have much resistance left. To make matters worse, a smallpox epidemic broke out; it cost a great deal of effort in the beginning to convince the people of the benefit of vaccinations, but ultimately they considered it a powerful magical agent

\footnotetext{
$4^{1} \quad$ Tijdschrift voor Inlandsche Geneeskundigen 7-2 (1899), inside front cover: correspondence.

$4^{2} \quad$ He became famous for the discovery of gonococcus in 1879, later called Neisseria gonorrhoeae in his honour.
} 
against the evil spirit of the smallpox scourge. The few physicians and vaccinators on Lombok were busy day and night combatting smallpox and other diseases: 'In this way they contributed greatly to the work of pacification required on Lombok after the days of conflict during the military expedition'. When it was quiet again, the population emerged from hiding places and started working on the land again. Then they were afflicted by malaria and abdominal disorders: 'Again the physicians helped us. Our medics contributed to bringing the people closer to us; the Dutch were apparently not just warriors and administrators; they could also avert disasters that the evil spirits cast over the people.' For Engelenberg the conclusion was clear: 'To conduct prudent propaganda to encourage the people's trust in Western medicine, surgery and obstetrics, the native doctors along with good nurses and orderlies are the appropriate agents'. We had already heard similar views from A. Pruys van der Hoeven and C. van Swieten and later in 1908 from the Commission charged with the reorganisation of the Civil Medical Service: 'Providing medical assistance on a large scale is one of the surest means of winning the trust of the population. Especially in the Outer Possessions that has proven to be true in a graphic way' (Bijker et al. 1908:43). The same style was used by a teacher at STOVIA, E.R.K. Rodenwaldt, who considered the dokter djawa the advance guard of Western civilisation and ascribed to them an appropriate role:

The students must be thoroughly persuaded that it is namely their task, because they were born there and probably understand the population's mental state better than the European hygienist can, to convince the population to adopt a more hygienic lifesyle with tact and compassion on the one hand, but also with firm scientific conviction supporting boldness on the other. As government-employed native doctors, they are the ones to make the population understand that the government means nothing more by the hygiene measures than to create a basis on which the progress of human society in economic and spiritual terms is made possible. ${ }^{43}$

43 Rodenwaldt 1926: 200. He was appointed professor of hygiene in Kiel in 1934. He was a confirmed national-socialist and participated in the Auslandsorganisation der NSDAP. After WWII he was dismissed as a lecturer because of his Nazi past, Klee 1997:195, 203, 311 (with thanks to Walter Bruchhausen, Medizinhistorisches Institut, Bonn). 


\section{NOT IN GOVERNMENT SERVICE}

Until now, we have referred almost entirely to dokter djawa in the service of the government. There were other employers than the government, however. The rulers in the Principalities had their own medical personnel from the start of the nineteenth century, some of whom were Western-trained. For example, the susuhunan of Surakarta had two dokter djawa, one or two Western-trained native midwives and a number of vaccinators in his service. The sultan of Yogyakarta employed one dokter djawa, five vaccinators and a chief vaccinator (Schoute 1936:185). ${ }^{44}$

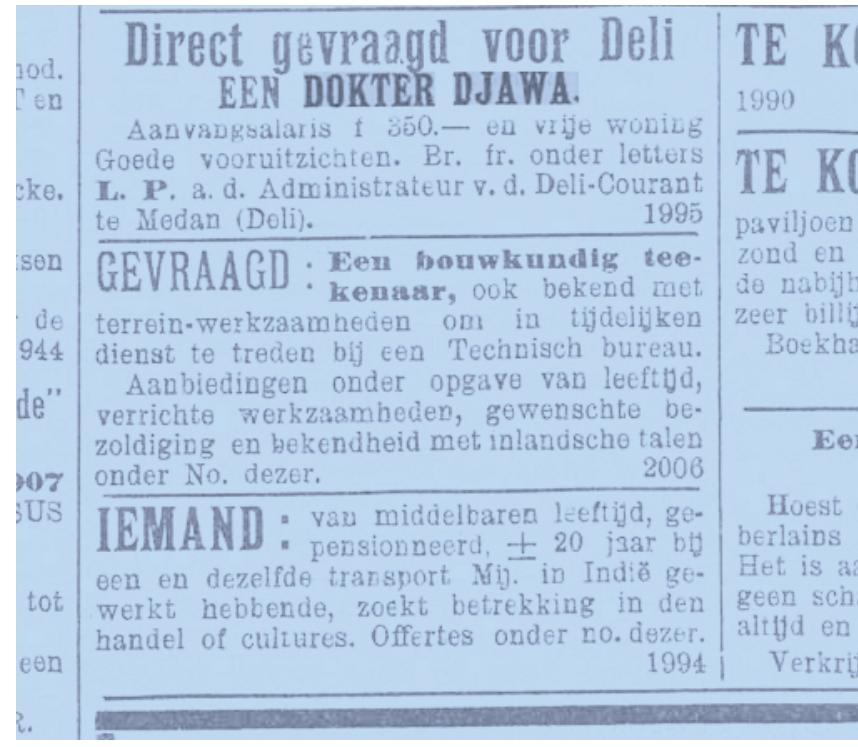

One of the many advertisements in which a company seeks to employ a dokter djawa

44 Het Nieuwes van den Dag voor Nederlandsch-Indï̈ 4-12-1905, p 4; 22-4-1907, p 4; 28-5-1907, p 4 (again a day later; this was a tobacco company in British Borneo); 31-5-1907, p 4 (repeated a day later); 17-11910, p 7 (repeated on 18, 19 and 20 January); 19-7-1910, p 7; 4-8-1910, p 7; 6-8-1910, p 8 (repeated on 8 and 10 August); 17-10-1911, p 4 (repeated for the next 2 days ); 17-1-1912, p 4 (repeated 14 times); 16-12-1912, p 4 (repeated on 19 and 21 December); 16-2-1915, p 4 (repeated 4 times); 11-7-1917, p 8 (repeated on 13 July); 6-8-1917, p 8; 14-9-1917, p 7; 5-11-1917, p 7 (repeated on the next 2 days; it concerned a company in Surinam). 
An increasing number of companies also required medical care for their personnel. The larger companies employed their own doctors: European physicians for the European personnel, and dokter djawa for the coolies. For example, the Billiton company had a dokter djawa certainly in 1878, the Batjan company did in 1885, and the Koetei coal company in southeast Kalimantan did in 1894. ${ }^{45}$ The private companies offered the dokter djawa attractive working conditions. During his tour through the Indies, the MP H. van Kol confirmed that the payment and the working conditions of a dokter djawa in the civil hospital in Bandung were abominable: 'Is it surprising that many of them, and particularly the best ones, look for work with less harsh treatment in private companies or in mining regions?'46 The Inlandsche arts Sitanala obtained work in 1916 at a branch of the Crediet- en Handelsvereeniging Banda and at Mr. Clark's firm on Awaya (Ambon). He earned $f 600$ per month and had in addition the right to free accommodations, free lighting, two servants, free passage first class to his place of work, and exemption from income tax. If he became ill, he was given three months' leave while retaining his salary, free first class passage to Surabaya and reimbursement of the cost of medical treatment there. The three-year contract was so attractive that Sitanala resigned from government service (Keppy 2004:242-3). The only benefit of a job in service to the government was that the contract was for an indefinite period. The risk of being dismissed from private employ was small, however, because if the contract was not renewed, he could always return to government service, where he would be welcomed with open arms. The shortage was that great. As the government always provided a safety net, it was worthwhile to try to establish a private practice, for example through an advertisement. ${ }^{47}$

The graduates in private service remained part of the medical community. There were also students who dropped out prematurely from the training programme to take up a better paid job outside medicine. The lack of educational facilities in the colony only amplified the problem. In 1892 the director of the school, the future Nobel prize winner C. Eijkman, noted that students from the Moluccas, after graduating

$45 \quad$ Respectively KV 1878:125; KV 1886:103; KV 1895:149.

$4^{6} \quad$ Van Kol 1903:577; He worked in the Indies in 1876-1884 and in 1886-1892 as public works engineer; afterwards he ran the coffee company Kajoemas on East Java from 1883. He was a MP for the Social Democratic Party (1897-1909), Janny de Jong 1989:264-6.

47 Het Nieuws van den Dag voor Nederlandsch-Indië 2-3-1907, p. 4 (repeated on 4 and 5 March); 19-121912, p. 7 (repeated a day later). 


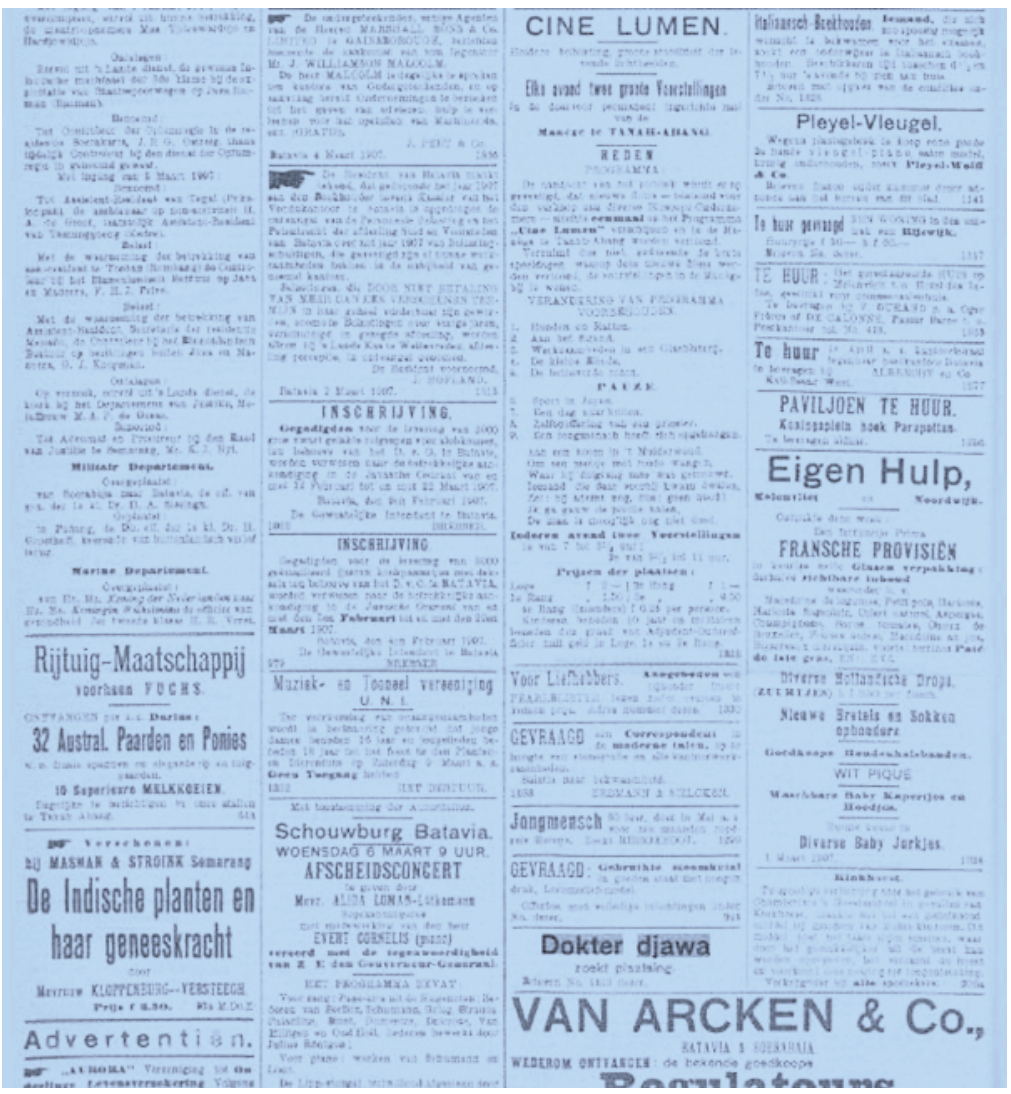

Advertisement from a dokter djawa looking for work

to the medical section, often strove to be expelled from the school $(K V$ 1892:122). One of the later directors, H.F. Roll, felt it did not encourage the learning process that many of the students expelled from the school soon found jobs with relatively high salaries. Expulsion did not work as a punishment (Jaarlïksch verslag STOVIA 1905:7). The Inlandsche arts W.K. Tehupeiory, himself Ambonese, did not find it strange that Ambonese students abandoned the training programme after a few years, given the poor prospects. With what they had learned, their knowledge of Dutch and some common sense, they could easily find another job with the gov- 
ernment with a much more favourable perspective. ${ }^{48}$ The government advisor Snouck Hurgronje confirmed that for older students, the future as dokter djawa was often frightful, so they tried to get expelled from the school to take up a more lucrative option. ${ }^{49}$

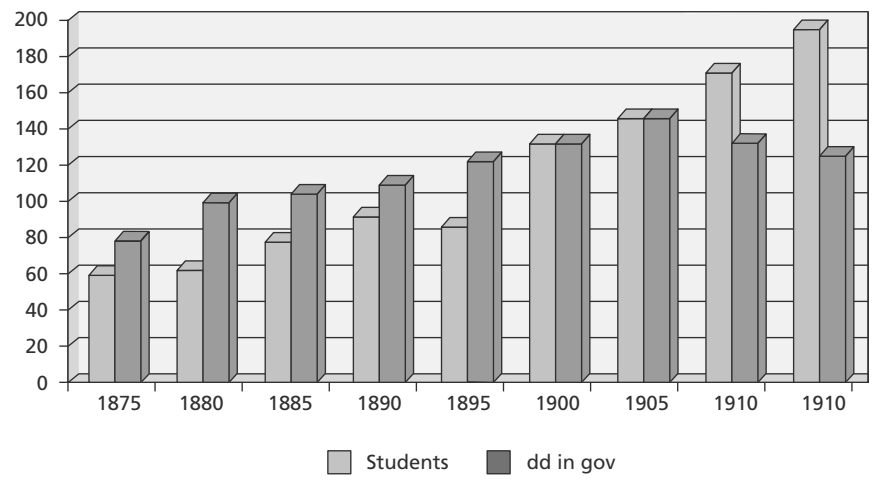

Graph 6.2. Number of students and number of dokter djawa $(\mathrm{dd})$ in government service in 1875-1915

Graph 6.2 shows that in the period 1875-1915 the number of students continued to rise, except around 1895. The number of dokter djawa and Inlandsche artsen in government service likewise increased until 1905 and then declined, a strong drop that is accentuated because the number of students continued to rise. In addition, the training programme lasted seven (in 1875) to ten years (in 1913), while the duration of service was 30 years. In other words, a person spent much less time as a student than as a doctor, so the number of graduates should have risen even more. With some exaggeration one could say that STOVIA trained doctors for the business community. The government was partly to blame for the unfavourable result because it offered the drop-outs jobs. The big loser was the Civil Medical Service: fewer doctors remained to fill the population's growing need for medical care.

$4^{8} \quad$ W.K. Tehupeiory 1908:110. In 1910 a sugar factory was looking for a warehouse manager; in the advertisement in Het Nieuwes van den Dag voor Nederlandsch-Indië(6-10-1910, p 7) graduates of the dokter djawa school were asked to apply.

49 Letter to director of Education, Religion and Industry 21-3-1898, Gobée and Adriaanse 1956:1041. 


\section{SHORTAGES}

The ethical policy increased the need for European and native doctors, as did the number of private companies seeking medical care for their personnel. Both the government and private entrepreneurs complained about shortages. Already in 1889 the director of Education, Religion and Industry, P.H. van der Kemp, mentioned in a circular to the regional administrators 'the large and urgent need for suitable dokter djawa that you are aware of.${ }^{50}$ During the cholera epidemic of 1902, the director of Education, Religion and Industry was besieged by various residents with requests for one or more dokter djawa, but there were none available (Kohlbrugge 1904:10-5). The administrator of the Liberia coffee company, Sagala Midar (Lampong), complained that so many coolies were ill.

If we had a doctor here, even just a dokter djawa, then we could at least distinguish the cheats from the real patients and thus save on an important contingent of currently wasted labour. But it is impossible to recruit a fulltime European doctor, it would be much too expensive, and we cannot be assigned a dokter djawa; only a limited number are available, and they are all employed by the government. (Doeff 1896:190.)

The last part cannot be correct because the government also suffered from a shortage. Native officials with a monthly salary under 150 guilders were not entitled to free medical treatment, unlike their European colleagues. When the MP Van Kol pointed this out to the minister of Colonies, T.A.J. van Asch van Wijck, Esq., in 1901, the latter promised to end this discrimination. ${ }^{51}$ But when examining the Indies budget for 1904, Van Kol noted that nothing had changed. The minister stated that there were still not enough dokter djawa to expand the group entitled to free medical treatment. ${ }^{52}$

The training programme was also negatively affected by the shortage. Given the scarcity of native doctors, the director of STOVIA abandoned the request for more assistant-teachers so they could continue

\footnotetext{
$5^{\circ} \quad$ Circular from director of Education, Religion and Industry to the regional administrators on and outside Java and Madura 9-10-1889 no. 10305, Bïblad 4530.

$5^{1} \quad$ Handelingen TK 1901-2, meeting of 27-11-1901, 198.

$5^{2} \quad$ Handelingen TK 1903-4, meeting of 26-11-1903, 516-8; Report 26th meeting of Lower Chamber of 26-11-1903 in: Bulletin Bond van Geneesheeren in Ned. Indië no. 11 (May 1904).
} 
treating the many patients attending the outpatient clinics (Faarlijksch verslag STOVIA 1903:8). In 1890 the director, C. Eijkman, proposed adding obstetrics to the curriculum. Despite the support of the head of the Medical Service, H. van Lokhorst, and the director of Education, Religion and Industry, P.H. van der Kemp, the proposal was rejected (Historisch overzicht 1898:54-5). The government was afraid that increasing the study load would negatively affect the number of graduates (Van der Burg 1896:1971). However, the subject was introduced in 1902 after all, although the shortage had still not been relieved.

\section{ALLEVIATING THE SHORTAGE}

To meet the increased need for more native doctors, the number of graduates had to be increased. It was first resolved that the graduates would no longer be used as vaccinators. In 1878 it was decided that about 40 vaccinators who had been trained at the dokter djawa school would be appointed as dokter djawa if their skills were still adequate. It was simple to find replacement vaccinators. This measure produced 13 dokter djawa.

In addition, in 1900 the maximum number of students was doubled from 100 to 200. The increase was not needed to cover the number of students registered at that time, so more focus was put on recruitment. In circulars the regional administrators were called upon to propose candidates. ${ }^{53}$ In addition, pressure was exerted in 1901 and 1902 on Director of the school Roll to accept more students. He did not intend to lower the standard, however (Roll 1909:52).

Incidental measures were taken to alleviate the greatest need. In 1901 it was decided to employ suitable students from the final academic year if necessary. ${ }^{54}$ This was done, for example, during the plague epidemic in Malang (Pasuruan) in 1911. Eight excellent final-year students were awarded their diploma without having to take exams and were immediately put to work combatting the plague (De Waart 1926a:50-1). As a last resort, the assistant-teachers of the school were employed. Raden

\footnotetext{
53 Circular end of 1875, KV 1876:123; Circular from director of Education, Religion and Industry to the regional administrators on and outside Java and Madura 9-10-1889 no. 10305, Bijblad 4530; Circular from director of Education, Religion and Industry to the principals of public primary schools in the Netherlands Indies 21-9-1891 no. 9382a, Bïblad 4776; a couple of years later the circular from Director Abendanon to the European school commission in the Netherlands Indies 13-9-1900 no. 12045a, Bijblad 57663.

$54 \quad$ GB 28-9-1901 no. 1, KV 1902:205.
} 
Soerjatin had to help out in 1902 with contagious diseases in Jakarta; his work at the school suffered as a result (Jaarlijksch verslag STOVIA 1903:8), but combatting the epidemic apparently took precedence. From 1906 a few retired dokter djawa were employed, for example at the Chinese hospital in Jakarta ( $K V$ 1907:appendix R), combatting smallpox in Mojokerto (Surabaya) and combatting malaria in Pasuruan ( $K V$ 1913:appendix T). In 1913 given the shortage of native doctors, 20 European nurses were recruited. ${ }^{55}$ The lack was also filled with laypeople, both European and native. Traditionally, controleurs had a medicine case; this 'privilege' was now also granted to the assistant-ministers, first in the Minahasa, later also elsewhere in the archipelago ( $K V$ 1893:130, note 1$)$.

\section{how to Retain them for the Civil Medical Service}

The student drop-out rate and the graduates' departure from government service stimulated the government to take measures to retain the graduates for the Civil Medical Service. One of the reasons for lowering the minimum age for admission to the school in 1879 was the hope that younger students would be less sensitive to the poor prospects of the dokter djawa and the allure of alternative options than older students ( $\mathrm{KV}$ 1879:121).

With the salary raise in 1899 , the government hoped to prevent the dokter djawa from being tempted by better offers from mining or agricultural entrepreneurs and leaving the national service prematurely $(K V$ 1899:119). This was unsuccessful because the new salary was still much lower than that offered by private companies. The MP Van Kol called this improvement half-baked. The government would only benefit partially from the expansion of the dokter djawa school, as it was unable to offer the same salary as private companies. ${ }^{56}$ The government quickly realised that this salary raise was indeed inadequate and resorted in 1901 to a very different measure, the so-called binding agreement. Upon admission to STOVIA, a candidate had to sign a declaration that he would serve at least ten consecutive years in government service after graduation, at any post to which the government would send him. ${ }^{57}$ The objective was obvious: '[G]iven the desirability of strengthening the bond

\footnotetext{
$55 \quad K V 1913: 12$ and $K V 1914: 114$.

$5^{6} \quad$ Handelingen TK 1899-1900, meeting 3-5-1899, 979.

57 Art. 9f Regulation 1902, Ind. Stb. 1902 no. 443.
} 
between the State and the dokter djawa, and thus preventing them from leaving for more lucrative employ with private companies, as has already frequently occurred' (KV 1901:82). If they left government service before ten years were up, they had to pay back the full cost, regardless of the number of years of service. As Graph 6.2 shows, the binding agreement was not the answer either: the line continued to drop. In 1909, 12 dokter djawa entered private service while 11 students graduated that year $(K V$ 1910:160). Two years later the situation had deteriorated further: 26 dokter djawa left the government service, and only 15 were awarded their diploma. ${ }^{58}$

\section{POSITION OF DOKTER DJAWA IN THE CIVIL} MEDICAL SERVICE

From 1890 onwards, the duties and responsibilities of European physicians were transferred in stages to native doctors. The first step was allowing a certain task to be carried out by dokter djawa when the European physician was absent. The next step was the native doctor performed this task himself, and it would only be done in his absence by the European physician responsible for the Civil Medical Service. ${ }^{59}$ The one exception was the inspection of prostitutes, which was reserved for European physicians. ${ }^{60}$ The fact that natives were now conducting tasks originally done by Europeans did not mean that they were paid the same. Their salary contrasted greatly with the Europeans': to temporarily fulfil the duties of the Civil Medical Service, a dokter djawa received an allowance of $f 25$ per month and a European physician $f 100$ to $f 300 .{ }^{61}$ For quarantine services, a European physician was paid $f 10$ for every inspection on board a ship and the native doctor, $f 3 .{ }^{62}$ These differences must have led to irritation over time. In addition, the conditions under

$5^{8} \quad$ KV 1912:134; De Sumatra Post 12-3-1915, p 10 mentions that between 1906 and 1913, 81 graduated while 118 dokter djawa left government service.

$59 \quad$ GB 9-10-1890 no. 7, Bïblad 4710; Art. 5 and 9, Reglement betreffende de bevoegdheid en verplichtingen van dokter djawa (Inlandsche geneeskundigen), Resolution from director of Education, Religion and Industry 2-1-1902 no. 32a, Bijblad 5663; Resolution Bogor 6-6-1902 no. 1, Bijblad 5719; Circular from director of Education, Religion and Industry 13-12-1909 no. 20152, Augustin 1914:3.

6o $\quad$ GB 1-3-1884 nr. 10, Verzameling bepalingen Inlandsche geneeskundigen 1901:70.

${ }_{61}$ Respectively, KV 1891:appendix BB, note 1, bb,cc,ll,mm,oo,qq; Appendix BB, note e, u,x,z,aa, ff,hh; Appendix BB note ij (150), gg (150-300).

$62 \quad$ Resolution GG 12-7-1881 no. 6, Ind. Stb. 1881 no. 157. 
which the dokter djawa worked were often wretched. During his inspection tours, the Civil Medical Service inspector, C. Winkler, often saw dokter djawa working on the porch of their own house, having to provide their own furnishings, even a sink in the operating room (Bijker et al. 1908, appendix II:213-23). He felt 'that it was going too far to require native doctors to provide the furniture for their service in a government building in this way'. ${ }^{63}$

\section{COLLABORATION OF EUROPEAN PHYSICIANS AND DOKTER DJAWA}

Sometimes European physicians and dokter djawa worked well together, but the sources mostly report tension. Good news is not exciting after all. Some European civil physicians insisted on having a dokter djawa in their posting and then assigning the majority of the tasks for the Civil Medical Service to them, while pocketing the allowance themselves. J.H.F. Kohlbrugge (1904:10-5), civil physician in Sidoarjo (Surabaya), felt this was unfair to the civil physicians without a dokter djawa as assistant who thus had little time for their private practice. He did not mention that the dokter djawa could hardly establish a private practice for himself. Dokter djawa Raden Goeteng Taroenadibrata (1926:282) did notice this, and he suggested that the European physicians feared competition: 'Not all that long ago, there were civil physicians, who wished to have native doctors as assistants under the condition that they did not practise'. In 1906 the Commission charged with the reorganisation of the Civil Medical Service talked about competition between Europeans and dokter djawa, which led to the European physicians neglecting their assigned tasks to support the development of the dokter djawa, which dated from 1856: 'They [European physicians] earn a large part of their income with the treatment of Chinese, and servants and labourers employed by Europeans. The greater the effort they invest in training the dokter djawa, the greater the risk that the latter would damage their own practice' (De Waart 1926a:6). This is echoed in A. de Waart (1919:92), first teacher and from 1925 director of STOVIA: further training of the graduates was just for show because the private physicians did not want to 'cultivate' their competition. 
The collaboration between European and native doctors culminated once in an open conflict. In 1901 P. Engelmaijer, civil physician in Bangkalan (Madura), asked the head of the Medical Service to transfer the dokter djawa because he did not do his work well enough: he had refused to visit a native because he was gambling with a Chinese. He was not transferred because, according to the head, this was a case of a less successful relationship, but then the dokter djawa tendered his resignation from government service. Due to the great shortage, this was also denied. Engelmaijer was ordered to point out to the dokter djawa that he would be eligible for a salary raise and transfer the next year. Engelmaijer submitted a protest to both the head of the Medical Service and the director of Education, Religion and Industry. When he did not receive a quick reply, he published this case in the Bulletin van de Bond van Geneesheeren in Ned.-Indië. His protest concerned the government protection of a poorly functioning native doctor, while punishment of European physicians who were accused of not doing their work properly was severe. He was referring to the suspension of two European doctors by the director of Education, Religion and Industry, J.H. Abendanon, a case that caused a commotion among European physicians. ${ }^{64}$ This case was given the revealing title 'Quod licet Jovi (the dokter djawa) non licet bovi (the European Physician)' (Schülein and Van Gorkom 1903:9-11). European physicians felt that double standards were being applied. This practical case supported their suspicion that for ethicists like Abendanon, a dokter djawa had an unassailable godly status. The shortage of native doctors was reflected in this case. The dokter djawa could resign because he knew he could easily find other work. The same shortage prevented the government from accepting his resignation. It is inconceivable that the government would postpone the right solution - transfer - by a year while the conflict was apparently escalating.

DEBATE ABOUT THE DOKTER DJAWA WITHIN THE CIVIL MEDICAL SERVICE

The ethical policy addressed the best form of medical assistance for the population. The native doctors played an important role in the discussion: should their training programme be extended, choosing quality, or

${ }_{4}$ They were J.K.J. Chambry in Jakarta and A. Ellinger in Tegal. Their suspension led to the establishment of the Bond van Geneesheeren in Nederlandsch-Indië, W.J. van Gorkom 1902:27. 


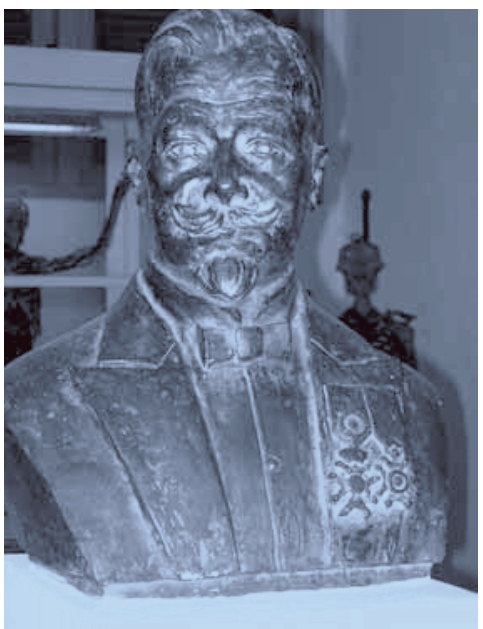

Bust of Roll. This is now in the anatomy museum in the Cipto Mangunkusumo Hospital, Jakarta (photo J.H. Peters).

should as many native doctors as possible be trained as assistants, choosing quantity? ${ }^{65}$

The former student Jacob Samallo (1926:291) recalled that there was talk of making the training programme easier. 'The government wanted to turn us into village doctors because then every year more medical assistants could be supplied. But Father Roll was not pleased. [...] Luckily for the institute and for our people, Father Roll managed to get his way.' The teacher Th.G. van Vogelpoel reported that the government, once it had discovered the dokter djawa were useful instruments, exerted pressure on STOVIA to supply as many students as possible each year. The head of the Medical Service, J. Haga, felt it was enough if the dokter djawa could recognise and treat simple diseases, but the director of the school, Roll, wanted to train the dokter djawa to be skilled doctors, who could win the population's trust in Western medical science (Van Vogelpoel 1926:139-40). The influence of Haga as head of the training

$6_{5}$ The viewpoints in this discussion match those in the debate on education. Snouck Hurgronje and Abendanon 'favoured an elitist approach. They wanted more European-style education in the Dutch language for a Westernized Indonesian elite'. Minister of Colonies Idenburg and GG Van Heutsz 'favoured more basic and practical education in vernacular languages for these lower levels. [...] Under Abendanon the elitist approach was favoured.' (Ricklefs 2001:199.) 
programme was greatly reduced in the new regulations of 1902 so that as Samallo noted - Roll enforced his will, partly thanks to the support of Director of Education, Religion and Industry Abendanon.

The civil physician Kohlbrugge (1904:10-5) felt it was wrong, given the pressing need for native doctors, to make the criteria imposed on the applicants stricter and to extend the duration of the training programme. He considered it more important to train assistant doctors, an approach he had good experience with. Others preferred no assistant rather than a partially trained one and thus favoured a few, well trained native doctors over assistant doctors. The mistakes of the latter would put European medicine in a bad light as far as the population was concerned.

Another question in the discussion was whether the dokter djawa could work independently. The civil physician W.J. van Gorkom (1904:35, 42-3) thought them incapable of doing so, and according to him that would never change. Many European physicians felt similarly (Bervoets 1898:380), as did even a director of Education, Religion and Industry. ${ }^{66}$ We see this idea also reflected in the clarification of a budget amendment. ${ }^{67}$

The discussion about the position of the dokter djawa was given an impulse around 1900 when the reopening of the midwives' school was considered. Opponents, such as Health officer A.A. Gersen (1901:5868), expected that expanding the competence and number of dokter djawa would bring greater improvement in the medical and maternity needs of the population than another midwives' school.

Clearly there was a range of opinions about the position of the native doctors in health care. A definitive standpoint was linked to the vision of the Civil Medical Service as a whole, which would be formulated in 1908 by the Commission charged with its reorganisation.

\section{DOKTER DJAWA BETWEEN TWO GULTURES}

The dokter djawa existed between two cultures in the colonial society. From their background, they belonged to the indigenous society. The

\footnotetext{
66 C. Bosscher, director of Education, Religion and Industry 1884-85, considered them 'at best as helpers under the supervision of European physicians', Laméris 1881:173.

${ }_{67}$ Handelingen TK 1898-99, appendix B, budget amendment no. 34, 2:'These physicians were supported by 80 dokter djawa, but management, supervision and initiative were only expected from European physicians'.
} 
government wanted them to return to their regions of origin after graduation to work as doctors. While attending the training programme, however, they spent many years in a European environment, and as the level of the training programme rose, this period became longer. There must have been consequences for being immersed in a Western lifestyle and mentality from a young age, far from one's family for seven and later ten years. This position between two cultures was difficult. ${ }^{68}$ The students dealt with it in different ways, as the following anecdote shows. An assistant-resident in Central Java shook everyone's hand at the ceremony honouring the assumption of his new post: the patih, the wedono, the penghulu and the jaksa. But he refused to shake the hand of a seconded Inlandsche arts, a Christian from West Java dressed in European clothing. He was highly insulted. The local dokter djawa, a Javanese, apparently sat quietly on a mat on the ground. According to the storyteller, dokter djawa Raden Goeteng Taroenadibrata (1926:283), it was an awful moment for both of them that they would remember for a long time.

ADAT

The position between two cultures sometimes led to tension, for example concerning the adat rule that a lower-ranking person could not allow a higher-ranking person to pay for a service rendered. This formed a problem for a dokter djawa (De Waart 1926a:6-7); in general, his indigenous patients belonged to the higher classes. In 1904 a resident reported that in his district dokter djawa were practically never paid by native officials and only rarely by Europeans. Dokter djawa submitted a bill only sporadically 'either because this was not generally accepted practice or they felt it was inappropriate or for fear that it would make people angry at them'. In a circular to all regional administrators, the government condemned such practices as using rank to avoid paying for medical services: 'The government considers it improper if officials take advantage of the existing misunderstanding or prejudice to be treated free of charge when they have no right to such service'. ${ }^{69}$ These strong words did not put an end

\footnotetext{
68 Van Niel 1960:56: 'Yet none of them [STOVIA, law school, et cetera] was equipped to help its Indonesian graduates to cope with the tremendous psychological and spiritual problems which followed as an aftermath from education that was tuned to a non-Indonesian way of life'.

69 Circular from first General-Secretary Paulus to the head officials of the Department of General Civilian Administration and the heads of the regional administration 23-9-1904 no. 3741, Bijblad 6086.
} 
to the practice, however, as appears from the following case. In 1906 a resident's secretary summoned a dokter djawa to his office to speak to him about an invoice for a European who had no right to free treatment. The invoice was only paid after the dokter djawa referred to the circular from 1904 in a letter to the secretary. W.K. Tehupeiory (1908:113-4) described this attempt at intimidation in 1908 to his audience in the Indies Society to illustrate the limited support that the dokter djawa received from the personnel of the resident's office. Apparently the European was so indignant that a native had dared to send him an invoice that he complained to the secretary in the resident's office, who in turn thought he could teach the dokter djawa a lesson. The latter was not intimidated, however, and spread the story among his colleagues. Thus, Tehupeiory came to hear of it in far-off Medan.

A very different adat rule concerned the umbilical cord that was only allowed to be cut once the placenta had been delivered. A dukun bayi kept to this rule. If the placenta was retained in the uterus, it presented a life-threatening problem for the mother and child. A dokter djawa had to tread carefully around this adat rule. J.E. Tehupeiory (1905:105-7) felt that the adat should be respected as long as it did not endanger the life of the mother or child. His recommendation to his colleagues read: 'Be careful of not appearing overly modern, as it creates alienation from the population'. He was convinced that the population would call on the dokter djawa more often once his expertise was more widely known. Until then, the native doctors would do well to respect the adat as far as possible and stick to the dukun's methods.

\section{INTERMEDIARY}

Some native doctors felt called to act as an intermediary between the indigenous society and Western medicine. The role of the dokter djawa as intermediary when considering the attempt of the government or its officials to make them assume that responsibility has been discussed. Below are examples of native doctors who themselves took the initiative to mediate.

Dokter djawa Raden Soemeroe (1898:51) was aware that he was useful and needed in the insane asylum in Bogor other than as an interpreter because he understood the Javanese mentality: 'As the terms for good and evil, stupid and clever, meant something different to natives than to Europeans, an assessment of abnormal or normal thinking would differ 
between the races'. The management of the Civil Medical Service must have had a similar idea, as one or two dokter djawa were always employed in the insane asylum in Bogor and one in Lawang (Pasuruan). In 1906 the Civil Medical Service inspector advised the director of Education, Religion and Industry to form a corps of native doctors specialising in mental illness. His arguments closely resembled those of Soemeroe: their familiarity with the native character, the language, the customs and the lifestyle of the village allowed them to empathise better with the indigenous patients than the European psychiatrists could, once they were trained for this special task. The Commission charged with the reorganisation of the Civil Medical Service supported this proposal; it would lead to considerable savings because then fewer European psychiatrists would be required. ${ }^{70}$ The Commission was clearly more concerned with the financial than the social-cultural factors.

Raden Moehamad Saleh Mangkoepradja, a dokter djawa in Sumedang (Priangan), wrote a midwifery handbook in Sundanese that appeared in 1901 and was translated into Malay a year later. ${ }^{71}$ In the introduction he wrote that native women, rich or poor, made use of the services of a dukun bayi during a delivery. Only when complications arose was a physician called in. Often it was then too late to bring the delivery to a successful conclusion. The woman blamed the physician and thereafter did not ask for his help so easily. Moehamad Saleh Mangkoepradja called on the women from the elite, priyayi, to read his handbook and talk about it with the dukun bayi. The latter would then realise how important it was to call in a physician earlier. The book is richly illustrated with realistic drawings of female genitalia and the stages of a delivery; this was probably intended to ease the transfer of knowledge. The author clearly felt like a representative of Western medicine and wanted to convey this knowledge to the dukun bayi through the priyayi-ladies and the illustrations. In this case, a second intermediary was required along with the dokter djawa - the priyayi-ladies - although it is questionable whether ladies from the elite would want or could act as intermediaries with the dukun bayi given the difference in their classes. In a long letter to the editor of a newspaper, one dokter djawa envisaged an intermediary role for him and his colleagues

\footnotetext{
7o Letter 13-1-1906 no. 7/2, Bijker et al. 1908:33.

$7_{11}$ Respectively, Kitab atoeran bab maradjian djělěma noe ngedjoeroe (1901) and Kitab pengadjaran bagaimana patoet orang menoeloeng sa-orang perampoean jang beranak (1902). With thanks to Mikihiro Moriyama, Professor of Indonesian Studies at Nanzan University (Nagoya, Japan), who drew my attention to this.
} 
in the schooling of dukun bayi by European physicians. This would work both ways because the dokter djawa would then also learn about obstetrics. ${ }^{72} \mathrm{He}$ wrote this letter before obstetrics was introduced as a subject at the school.

Indische arts Zainal (1926:318-9) used the word 'propaganda': 'The native doctors must therefore consider it a respectable and fine duty to spread propaganda among the population tactfully, with patience, selflessness and serious work, and to stimulate the necessary trust in our great work'. He considered it important that the outpatient clinics should be 'robust and tidy stone buildings, to make an exceptionally favourable impression on the population's ideas about Western medicine'. He felt that outpatient clinics were calling cards for Western medicine.

We also find this point of view expressed by Indische arts Goelam (1926:326-7). He had noticed that the population only called for a physician when the dukun was unsuccessful. He wanted to make the population aware that the Koran commanded every Muslim to seek competent treatment when ill: 'And where the native doctors $[. .$.$] come into contact$ frequently with the population on account of their work and get to know them better and sooner, in my opinion enlightening them forms part of our task'.

The physician Raden Mas Noto Kworo (1918:71), trained in Leiden, wanted to achieve the same in the field of obstetrics. He understood that this formed a serious challenge to the indigenous customs and that it would not be an easy task: 'But if we, as sons of this country, familiar with the language and informed about the adat and customs, act with tact and care and patience, we believe that we shall succeed in alleviating the suffering of our sisters in the most difficult period of their lives'.

Kartini envisaged a dual form of intermediary role for the dokter djawa: 'What couldn't he do to promote the mutual appreciation of the European and the native element. He could acquaint the people with European medicine and draw attention in the European world to simple indigenous remedies, whose effectiveness has been confirmed. ${ }^{73}$

$7^{2} \quad$ Het Nieuwes van den Dag voor Nederlandsch-Indië 21-12-1900, p 1-2, titled 'Het streven van dokters djawa naar meer kennis' [Native doctors strive to increase their knowledge]. He signed himself as 'a dokter djawa'.

73 Letter to Abendanon 14-1-1903, Jacquet 1987:265. 


\section{VIEWS OF THE DUKUN}

The dokter djawa had a range of views about the dukun. Some respected their expertise, especially in the areas of abdominal disorders and skin diseases and midwifery. ${ }^{74}$ Others went further and devoted themselves to getting medications they had 'borrowed' from a dukun incorporated in European apothecaries, such as Soeriadarma (1897:12-6) with babakan turi (cortex agati grandiflorae), an effective agent to treat chronic malaria. But there were also those who acted as representatives of Western medicine and, convinced of its superiority, denigrated the dukun's methods. For example, the dokter djawa in Sawahlunto (Sumatra's West Coast) considered massage just superstition, which could not compete with medical practice. ${ }^{75}$ He wrote disdainfully about dukun who 'just started' massaging without a diagnosis (Sm 1893:89-91). Tjipto (1905:139-43), Asharie and Si Moro used Latin to assert that they belonged to the world of Western medicine. Asharie called on his colleagues to conduct a trial of a Javanese remedy against katarrhalen icterus (inflammation of the liver, hepatitis), namely 25 living pediculi capitis (headlice) in a piece of ripe banana. ${ }^{76}$ On the one hand, he was utilising Latin, even for headlice, on the other he asked his colleagues to seriously consider a nonsense remedy. This case shows the equivocal position of the dokter djawa. Si Moro (1894:32) employed the Latin term venaesectie to describe how a dukun collected a few drops of blood by pricking the nose of a child with a thorn.

There were also pragmatic native doctors. For example, Permadi (1915:9-15) advised his colleagues to monitor the dukun during a circumcision and to make sure that both the dukun's hands and the surgical field were clean and that the boy's penis was examined for abnormalities. Samir (1909:19-21) described the dukun bayi in his article as a magician wielding hocus pocus, but pointed out the extenuating circumstances where even in modern, well-equipped maternity clinics the new mothers did not always have it easy: 'While nowadays even in excellently equipped maternity clinics there are still cases of febris puerperalis

\footnotetext{
$74 \quad$ Intestinal and skin diseases: Kardjo 1896:78-9; Mohammad Dagrim 1899:22-4; Renong 1893:73; Moehali 1895:12-3. Obstetrics: Soeriadarma 1896:10-2.

75 Tijdschrift voor Inlandsche Geneeskundigen 1-5 (1893) inside back cover.

$7^{6} \quad$ Tijdschrift voor Inlandsche Geneeskundigen 10-2 (1902):31, under the heading Kleine Mededeelingen [Short Reports].
} 
found, it is hardly surprising that dukun with their hocus pocus and especially with their disinfected fingers do so much damage to their sisters'.

These case reports come from the Tijdschrift voor Inlandsche Geneeskundigen. The dokter djawa who published in Dutch must have felt attracted to the West. But even within this group, there was a variety of views on the dukun.

\section{CLOTHING}

Around 1900 the indigenous elite began to feel the need to wear European clothing more often, but that was not permitted in public. One was expected to wear the clothing appropriate to one's own ethnic group. A native was not meant to dress like a European, and a Chinese was not allowed to cut off his queue (Vanvugt 1988:40). In 1902 a correspondent from Surabaya wrote indignantly in the newspaper about a dokter djawa who dressed as a European: 'It is not clear to me which regulation allows him to do that'. ${ }^{77}$ In the same year a dokter djawa, Raden Moekadi, submitted a request to permit native doctors to wear Western clothing with a traditional headdress. ${ }^{78}$ In response, the government consulted its advisor Snouck Hurgronje. Because traditional dress varied in the indigenous society and was subject to change, he felt that natives could wear European clothing. It was after all more practical and looked more civilised: 'Natives who have undergone a Western education are starting to be embarrassed about their dress, which inadvertently, especially in European society, is associated with the image of a lesser civilisation and a lower rank in society'. He advised the government to inform Raden Moekadi that it had no objection to the inclination of dokter djawa and other native officials to dress more or less as Europeans and that no separate stipulations were required for this. ${ }^{79}$ The government adopted his recommendation in its entirety. ${ }^{80}$

Native doctors took advantage of this possibility and stated why they wanted to wear Western clothing: 'Partly, discarding native clothing is intended to escape from the often ill-mannered treatment by the European

\footnotetext{
77 Het Nieuwes van den Dag voor Nederlandsch-Indï 4-3-1902, p 3, 'Over het paard getild' (Swollen head).

$7^{8} \quad$ Circular from first General-Secretary Paulus 2-6-1903 no. 1844, Bïblad 5941.

79 Letter to director of Education, Religion and Industry 26-10-1902, Gobée and Adriaanse 1956:1041-5.

8o Circular from first General-Secretary Paulus 2-6-1903 no. 1844, Bïblad 5941.
} 
personnel of railways, trams, etc.; also, European clothing is more practical for doctors' (Apituley et al. 1910:14). Others, such as J. Westplat (1913), ascertained that native doctors started dressing in European fashion because in their national dress the less educated native officials looked down on them. In European clothing they could move more easily in decent European circles where they were appreciated as men with refinement. Wearing Western clothing does not have to be viewed as taking the side of the colonial oppressor; the first president of Indonesia Soekarno was proud of wearing Western clothing. He ridiculed every native who still wore the traditional sarong by saying that he looked like a woman (Gouda 1998:245). The photo of dokter djawa Samgar (see p. 115) shows that not all native doctors preferred Western clothing.

Over time, the students' clothing also changed; around 1910 they wore trousers under their white coats rather than a kain and a black jacket. ${ }^{81}$ Apparently, the fear that wearing Western clothing would lead to estrangement between the native doctors and their fellow countrymen had disappeared. The members of the Commission charged with the reorganisation of the Civil Medical Service thought differently in 1908: '[T]o help with the lifting up of the indigenous people, he [the dokter djawa] had to remain native, if not in his world view then in his lifestyle, his manners, his physical appearance, even in his clothing' (Bijker et al. 1908:75).

The native doctors wore Western clothing to escape from their position between two cultures. The next step was aiming for the same title as the Netherlands-trained physicians. This required an extension study in the Netherlands.

\section{STUDY IN THE NETHERLANDS}

In 1899 dokter djawa Abdoel Rivai departed for Utrecht, where Eijkman, the former director of the dokter djawa school, was a professor. He was allowed to attend lectures but not take exams. When he discovered that doctors from the Dutch West Indies were allowed to do so, he submitted a request to the government - supported by the MP C.Th. van Deventer - to be granted the same rights as the doctors from the West Indies. His request was sent to the East Indies for advice (Sardjito 1936:22-3). It received several negative evaluations: from the head of the Medical Service, from the

81 Letter from director of STOVIA to head of Medical Service 28-6-1913, Van Dijk 1997:59. 
Bond van geneesheeren in Nederlandsch-Indië, and from the Vereeniging tot Bevordering der Geneeskundige Wetenschappen in NederlandschIndië (Physician's Federation in the Netherlands Indies). ${ }^{82}$ According to them, the request was apparently unfair to Dutch students who followed a much more rigorous course. There were also doubts about whether the native doctors were capable of following a university course. In addition, the request was considered unnecessary because the native doctors were already fully qualified in the Indies. ${ }^{83}$ Despite protests from the Indies, Parliament carried the amendment to the act; ${ }^{84}$ from 1904 native doctors were admitted to Dutch universities (Ind. Stb. 1904 no. 487). The Bond van Geneesheeren spoke of 'a slap in the face of Dutch physicians' ${ }^{85}$ Abdoel Rivai had not waited for the outcome of the procedure; he went to Ghent (Belgium) to study, where he was awarded a doctorate. The native doctors had to pay for their course in the Netherlands themselves at first; in 1911 the Max Havelaar Foundation was established to grant subsidies to promising upper-class native men to study at institutes of higher learning in the Netherlands pending the establishment of a university in the Indies itself (Gouda 1995:86).

When Abdoel Rivai announced his plan to study in the Netherlands, his family and friends responded negatively. A few years later the attitude changed, and the indigenous society had a much more positive view of the Netherlands. In addition, the pioneers had informed them that they were better treated in the Netherlands than by the Dutch in the Indies (Abdoel Rivai 1906). The STOVIA graduates were shown respect; according to some their heads were turned from all the attention. ${ }^{86}$ As showpieces of the ethicists, they visited the homes of the elite such as the MP Van Deventer. They attended meetings of the illustrious Indies Society, ${ }^{87}$ where they met ministers and MPs. Sometimes they were invit-

\footnotetext{
82 Respectively, Roll 1909:65, note 1; faarverslag over 1903 1904:xv; Bijker et al. 1908:68.

$83 \quad$ Sardjito 1936:22-3; Jaarverslag over 1903 1904:xv; Bijker et al. 1908:68.

$8_{4}$ Handelingen TK 1903-04, meeting 27-4-1904, 1576-7. Radjiman and C.R. van Joost, both dokter djawa, had sent a supporting petition to Parliament.

$8_{5} \quad$ Hoofdbestuur 1912:26; Van Effen concluded from the equal treatment that the government had little regard 'for our science and our art', 1905:37-48. Het Nieuwes van den Dag voor Nederlandsch-Indië 16-6-1915, p. 2 copied a report from the Bataviaasch Nieuwsblad in which Senior, an anonymous critic, protested the admission of native doctors to universities in the Netherlands.

$86 \quad$ Bijker et al. 1908:77: 'Everything colluded to delude him into believing that only the name differed a little; in essence he considered himself equal, except for a formal step'.

87 The first time was on 22-10-1907; the chair introduced with pride Mas Boenjamin, Mas Asmaoen, Abdoel Rivai and the Tehupeiory brothers, De Vogel 1907:1.
} 
ed to be guest speakers: W.K. Tehupeiory in 1908 was the first Moluccan and Radjiman in 1911 was the first Javanese at the Indies Society, as was J.E. Tehupeiory at the 30th Nederlandsch Taal- en Letterkundig Congres (Netherlands Language and Literary Congress). The Tehupeiory brothers had an interview with the minister of Colonies, A.W.F. Idenburg, and handed him a list of suggestions for improving STOVIA. ${ }^{88}$ The minister promised to contact the governor-general about it. ${ }^{89}$

\section{OWN SOCIETY AND PERIODICAL}

From 1883 a few dokter djawa became members of the Vereeniging tot Bevordering der Geneeskundige Wetenschappen in Nederlandsch-Indië. In 1902 it was decided that the Vereeniging would be purely medical from then on. In his annual speech, the chair confirmed to his regret that veterinarians could no longer be members, but he kept quiet about the fact that dokter djawa could only be associate members from then on. Strange because dokter djawa as doctors suited the medical character of the Vereeniging, and precisely in that year improvements were implemented in the training programme. Perhaps the idea was to keep the Vereeniging purely European.

A few years later, in 1911, the native physicians established their own organisation, the Vereeniging van Inlandsche Geneeskundigen (Society of Native Doctors), to promote the intellectual and social interests of its members as well as public health. ${ }^{90}$ In his retrospective at the 25 th anniversary, W.K. Tehupeiory (1936:4) specified the following motives for its establishment: the meagre salary of the native doctors, the discourteous treatment by both their European and native superiors, and the general discrimination against natives in society. Therefore, as educated natives, they needed a centre to discuss important matters and prepare reforms. The society had its own publication, the Orgaan der Vereeniging van Inlandsche Geneeskundigen (Organ of the Society of Native Doctors); later the word 'Inlandsche' would be replaced by 'Indische'.${ }^{91}$

On the one hand, the native doctors now had the right to obtain a

\footnotetext{
88 According to Poeze 1986:60 only J.E.; according to Keppy 2004:165-7 both brothers.

89 Letter from W.K. Tehupeiory to all alumni, Keppy 2004:165-7.

$9^{\circ} \quad$ Accredited by GB 29-9-1911 no. 58, Vereenigingen 1921:550. The plan for a society like this originated in 1908, W.K. Tehupeiory 1936:4.

${ }^{1}$ The change was brought about at the same time when the name of the school was changed in the same way. This was necessary because from 1913 all races were admitted.
} 
Dutch physician title in the Netherlands; on the other, they were not taken seriously by their European colleagues in the Indies. An obvious reaction to this situation was to establish a separate society of their own. One step further was to participate in the nationalist movement.

\section{NATIONALISM}

On 20 May 1908 Boedi Oetomo was established at STOVIA. The foundation date has gone down in history as the start of Indonesian nationalism (Bosma and Raben 2008:318). The current museum of the nationalist movement, Museum Kebangkitan Nasional, is housed in the STOVIA building. The initiative to set up Boedi Oetomo came from Mas Wahidin Soedirohoesoedo, a retired dokter djawa. In 1906 he travelled all over Java to convince higher- and lower-ranking native officials of his ideas. First of all, he wanted to establish a study bursary for Javanese children (Boedi Oetomo 1917:321-2). He believed that the Javanese could raise themselves up through Western education and strengthening their own culture. His ideas resonated with the students of STOVIA. The establishment of Boedi Oetomo gave STOVIA the reputation of an institute where the students could develop their nationalism. In an interview with Hans Beynon, various interviewees stated that at STOVIA they experienced what was called 'the Indonesia-feeling'. ${ }^{92}$

Participation in the nationalist movement could also be problematic as the example of Tjipto Mangoenkoesoemo reveals. ${ }^{93}$ After his exile to the Netherlands in 1913 because of nationalist activities, he returned to the Indies in 1914. He hoped to be able to take up his medical practice in Surakarta again. The local Islamic press welcomed the idea of a doctor in town who would care for the poor patients, but with his reputation Tjipto attracted few paying customers. He unsuccessfully attempted to become the personal doctor of the mangkunegara; ${ }^{94}$ the resident also refused to give him a place on the medical staff to combat the plague (Van Dijk 2007:463-4). By choosing for the nationalist movement, the ambivalent position of the native doctors was highlighted: while one

\footnotetext{
$9^{2}$ Citation from Aziz Saleh, minister in various cabinets under President Soekarno. Other interviewees were Johanna Masdani-Toemboean and Sapoean Sastrosatomo, respectively, in Beynon 1995:97, 33, 138.

93 Originally he was called Tjipto.

94 One of the four rulers in the Principalities.
} 


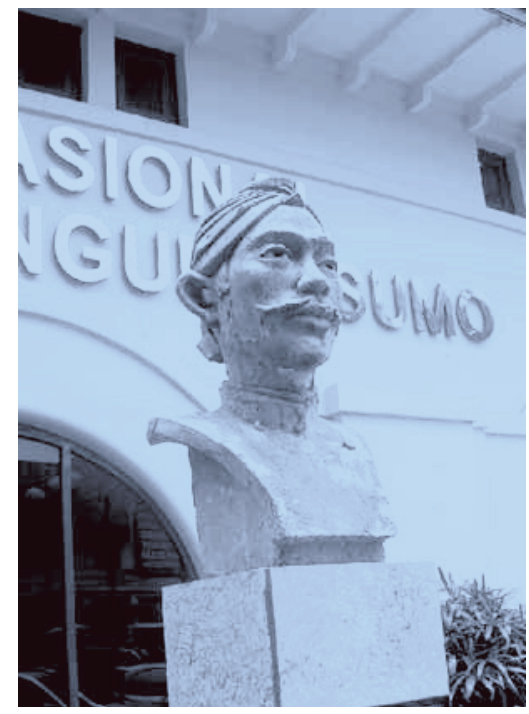

Bust of Tjipto in front of the hospital in Jakarta bearing his name (photo J.H. Peters)

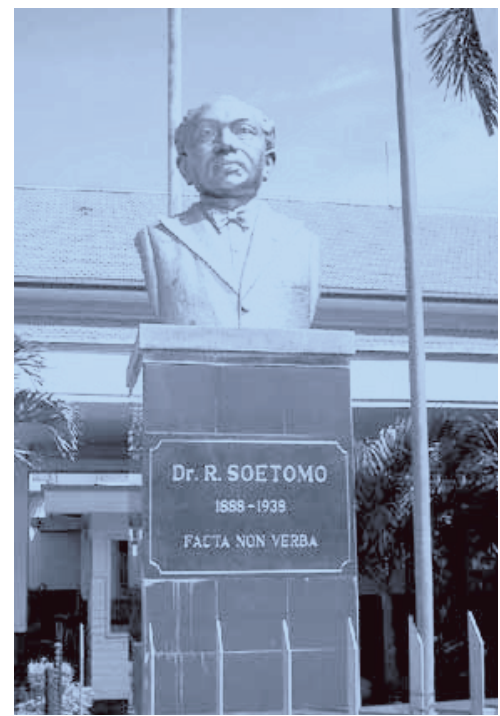

Bust of Soetomo in front of the university named after him in Surabaya (photo J.H. Peters) 
party had high expectations of Tjipto, he was persona non grata for the other.

\section{STATUS OF GRADUATES}

\section{STUDENTS' BACKGROUNDS}

The management of STOVIA divided the students into three groups according to their origin: high, middle and low. The native doctors belonged to the middle category, as did teachers, assistant-district heads, mantri and vaccinators. ${ }^{95}$

\begin{tabular}{|l|c|c|c|c|c|c|c|}
\cline { 2 - 8 } \multicolumn{1}{c|}{} & \multicolumn{2}{c|}{$\mathbf{1 8 7 5} \mathbf{- 1 8 8 4}$} & \multicolumn{2}{c|}{$\mathbf{1 8 8 5} \mathbf{- 1 8 9 4}$} & \multicolumn{1}{c|}{$\mathbf{1 8 9 5} \mathbf{- 1 9 0 4}$} & Total \\
\cline { 2 - 8 } \multicolumn{1}{c|}{} & Students & $\mathbf{\%}$ & Students & $\mathbf{\%}$ & Students & $\mathbf{\%}$ & \\
\hline High & 10 & 7 & 46 & 18 & 90 & 27 & 146 \\
\hline Middle & 22 & 15 & 97 & 38 & 159 & 48 & 278 \\
\hline Low & 115 & 78 & 112 & 44 & 83 & 25 & 310 \\
\hline Total & 147 & 100 & 255 & 100 & 332 & 100 & 734 \\
\hline
\end{tabular}

Table 6.2. Social background of students 1875-1904

(faarlijksch verslag STOVIA 1906:appendix 10)

In the 'high' category were the sons of important officials such as district heads. In absolute terms, there were few students in this group, but their percentage rose in the 1875-1904 period. Gradually, the training programme seemed to be gaining in popularity among the elite, the priyayi. The granting of the payung in 1882 may have been a factor in this. In addition, the only students being admitted now had attended the European primary school, and they were by definition from the upper class of the population. These students moved down the social ladder compared with their fathers, who belonged to the 'high' category. As relatively more sons from the high category applied for the medical training programme, this suggests that the status of native doctors rose over time to the upper limit of the middle category.

95 Jaarlijksch verslag STOVIA 1906:appendix 10. 
In the 'middle' category belonged the sons of intermediate-ranking officials such as dokter djawa and teachers. The proportion of students in this category rose during the 1895-1904 period to almost half.

In the 'low' category were placed the sons of minor officials and private individuals such as writers and village heads. Students from this category thus rose up the social ladder. The proportion of this group declined strongly over time from $3 / 4$ to $1 / 4$, probably due to the higher admissions criteria in the later period. The parents of these boys would not usually have had the money to give their sons the required preliminary primary school.

\section{PERCEPTIONS OF THE GRADUATES}

Those are the facts so far. The authors of sources perceived the situation differently. Raden Mas Margono Djojohadikusumo wrote in his memoirs about the STOVIA students' background: 'In my youth, the dokter djawa school or STOVIA was always characterised as the school "for the poor people". Only less well-off parents sent their children to that school because of the free accommodation and training programme.' A bit later he even refers to 'poor beggars' (Margono Djojohadikusumo 1970:39).

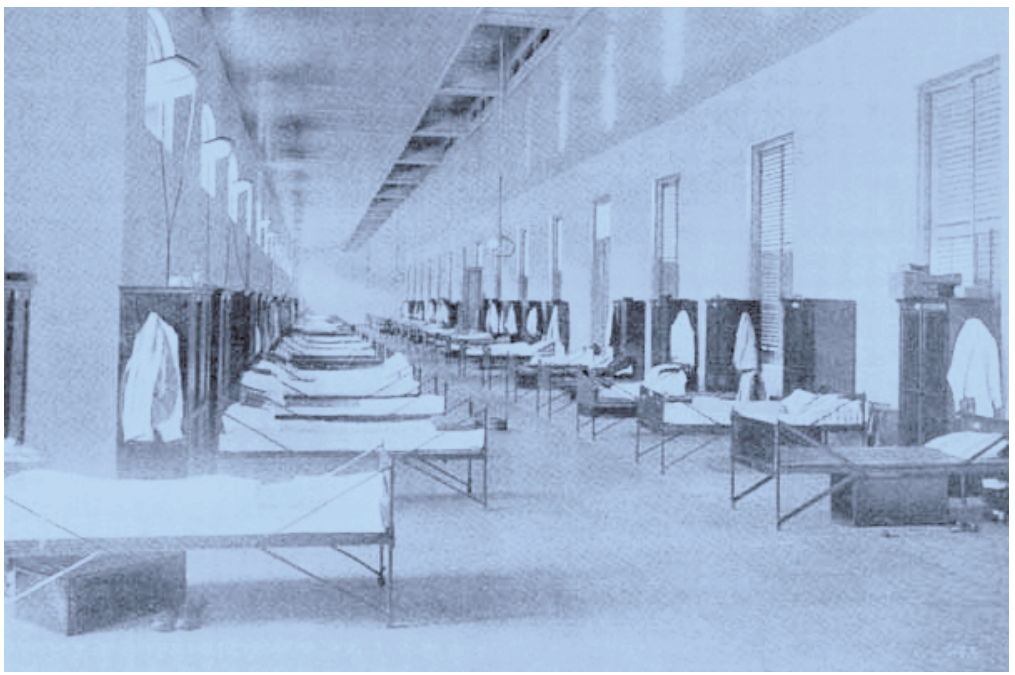

Dormitory at STOVIA (photo collection KITLV 35818) 
Later he repeated this: 'In my youth when I was still at primary school in Banyumas, the STOVIA was considered a "poor people's institute", (Margono Djojohadikusumo 1970:129). The students were housed in a boarding school, where they slept in large dormitories on cots. This was very different from the other boarding schools for native children, such as the OSVIA or the teacher training colleges, where each student had his own large room with a bed, cupboard and desk (Margono Djojohadikusumo 1970:28, 129). When considering these comments, we must remember that Margono, who attended the OSVIA (Margono Djojohadikusumo 1970:13), came from an impoverished Javanese aristocratic family and was kin to the sultan of Yogyakarta (Margono Djojohadikusumo 1970:6, 12). He thus belonged to the 'high' category.

Priyayi were generally administrators, civil servants. Their sons often went to the OSVIA. The choice of a practical career such as a doctor did not occur to the parents of Raden Soetomo, but after his mother had a dream, he went to STOVIA after all. His friend Mas Soeradji also ended up there after he was refused admission to the OSVIA (Van der Veur 1987:33). In the biography of Raden Mas Tirto Adhie Soerjo, who started at STOVIA but never finished, Pramoedya Ananta Toer wrote that a 'Raden Mas' rarely wanted to become a doctor. The higher nobility attended the OSVIA as a matter of course: 'That was self-evident, because a doctor had to be subservient, while a civil servant was in charge', according to Pramoedya's clarification. ${ }^{96}$ Although this assertion can be shown to be incorrect (in the period 1875-1904 there were 47 students at STOVIA with the title Raden Mas), ${ }^{97}$ it speaks volumes about how the dokter djawa were perceived. The municipal physician De Vogel (1906:37) also ascribed the lack of popularity of the medical course among the higher class to the subservient attitude required of the doctor, even towards people from a lower social class:

Undeniably, the desire to study medicine is not widespread among the indigenous nobility, and they currently display a certain reluctance to allow their sons to study to be a native doctor, who as I myself have heard them say 'will not achieve anything more than the rank of assistant wedono and for their entire life be the slaves of any coolie who claims to need their help'.

$9^{6} \quad$ Pramoedya Ananta Toer 1988:33.

97 Jaarlijksch verslag STOVIA 1906:appendix 11. 
On the one hand, both European and native authors of sources looked down on the dokter djawa because they came from a lower class than the priyayi. On the other, they were criticised because they apparently put on airs and behaved like priyayi. In a talk with dokter djawa Raden Goeteng Taroenadibrata, Governor-General A.W.F. Idenburg said that some of his non-noble colleagues had become arrogant: they did not want to acknowledge their parents and ignored their own fathers because they were only simple servants (Goeteng Taroenadibrata 1926:286). Idenburg exaggerated grossly here. In total, only three sons of servants were admitted as students in the 1875-1904 period, of whom one obtained a diploma (faarlijksch verslag STOVIA 1906:appendix 10). Others, such as the board of the Bond van Geneesheeren, accused the dokter djawa of lacking savoir viore, which was expected of the priyayi. The board ascribed this to the fact that many were sons of policemen, orderlies and similar lowly trades (Hoofdbestuur 1912:27, note).

The government advisor Snouck Hurgronje understood why a dokter djawa did not succeed in achieving the living standard expected of the priyayi class:

In education the native doctors stand far above the majority of native officials; their rank remains the lowest, irrespective of years of service and merit, and their income lies far below the criteria imposed by association in the priyayi's world. [...] Although, according to the statements of many European physicians, in knowledge they are not far below the average European physician, they have to raise their children as ordinary village children for lack of money. ${ }^{98}$

Snouck Hurgronje felt that native doctors were dissatisfied with their lot. They saw their contemporaries progressing in rank and income although they were much less well educated. This led them to carry out their jobs with increasing reluctance. ${ }^{99}$ A dokter djawa might be better educated than most native officials, but he still occupied a low rank in the civil service. This was apparent at official events like the January 1st celebrations or Lebaran, the end of the Islamic month of fasting, when all native

$9^{8}$ Letter to director of Education, Religion and Industry 21-3-1898, Gobée and Adriaanse 1956:1040.

99 Letter to director of Education, Religion and Industry 21-3-1898, Gobée and Adriaanse 1956:1040-1. 
officials had to congratulate the assistant-resident or the regent. Dokter djawa Raden Goeteng Taroenadibrata (1926:283) explained that there were only chairs for the patih, wedono and jaksa. The others, including the dokter djawa, had to sit on the ground. Between the lines we can read that he found this denigrating for a dokter djawa. In the twentieth century the government wanted to abolish this discrepancy, but it persisted. In 1906 the governor-general emphasised again in a circular that this improper discrimination was no longer in fashion. ${ }^{100}$ Some elderly dokter djawa preserved this tradition, such as the retired Mas Wahidin Soedirohoesoedo, who in 1908 still refused a chair next to the regent of Serang, Pangeran Aria Achmad Djajadiningrat, no matter how hard he tried to offer it to him (Djajadiningrat 1936:244-5).

We note that the perception of the status of the dokter djawa was lower than the status based on the classification by the management of STOVIA. The fact that many authors of sources came from the high priyayi class is the likely explanation for this.

\section{DIFFICULTY FITTING IN}

It was not easy to incorporate the dokter djawa in either the European or the native civil servant hierarchy. Since 1875 Dutch had been the language of instruction at the dokter djawa school, and from 1889 a good mastery of Dutch was an admission criterion, but in practice hardly any European official spoke Dutch with the graduates, and not with the dokter djawa nor with the native heads who were fluent in Dutch. The tea planter Karel Holle deplored the fact that some European officials considered speaking Dutch with natives beneath their dignity (Van den Berge 1998:199). Many priyayi were proud of their mastery of Dutch and found it awkward to speak formal Javanese to a European civil servant who barely spoke the language and often answered in Malay (Sutherland 1979:37). This was apparently so common that the first general-secretary in 1890 sent out a circular on behalf of the governor-general, in which all European officials were urged to speak Dutch with native officials who had been educated in it at government expense. ${ }^{101}$ The circular had insufficient impact because in 1898 Snouck Hurgronje advised the director of Education, Religion and Industry to remind the European

$100 \quad$ Circular 3-4-1906 no. 974, Bijblad 6496.

101 Circular 10-9-1890 no. 2198, Bïblad 6496. 


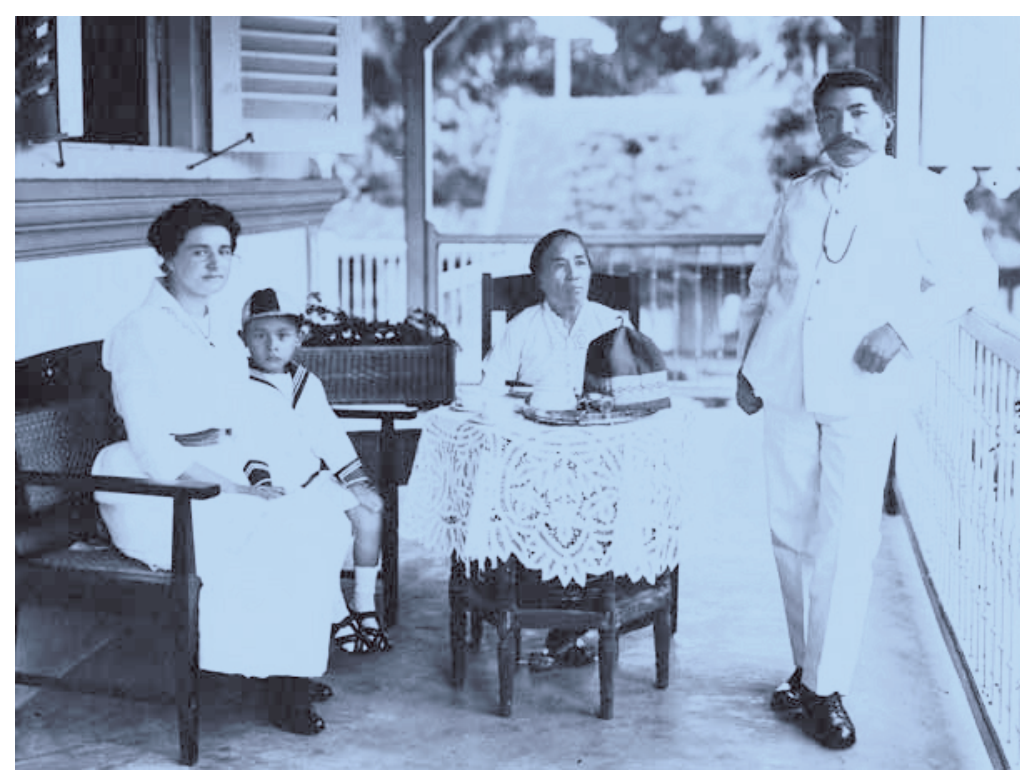

W.K. Tehupeiory and his family on Bangka around 1915 (photo collection IISG, BG C 16/57)

administrators regularly that they must treat the native doctors in accordance with their education and development: 'In that respect, many administrators fail worryingly in their duty when they treat the dokter djawa with no more respect than the lowliest village inhabitants, display irritation when they are addressed in Dutch and such like'. ${ }^{102}$ European officials continued to respond with annoyance when a dokter djawa dared to speak to them in Dutch. Therefore, a new circular was issued in 1906 in the hope of repressing this vile custom once and for all. ${ }^{103}$ It seems the habit could not be eradicated as Stokvis-Cohen Stuart (1931a:31) confirmed several years later: 'It is only a short while ago that Europeans would not tolerate the rudeness of a native addressing them in Dutch, or as something unbecoming'.

The problems were not restricted just to the Dutch language; incorporating native physicians with a Dutch medical diploma in the Civil Medical Service led to unanticipated problems for the government.

102 Letter 21-3-1898, Gobée and Adriaanse 1956:1041.

103 Circular 3-4-1906 no. 974, Bïblad 6496. 
Which position should these natives be given and where did they belong in the two social worlds? The career of Mas Asmaoen, one of the first native physicians who graduated in Amsterdam, illustrates this dilemma. In 1907 he submitted a request to become a health officer. It took an amendment in the law before he could become the first native health officer. However, his career in the army was sabotaged by the refusal of the Dutch officers to treat him as an equal. He was transferred to New Guinea, became ill and returned permanently to the Netherlands, where he died in 1916 (Poeze 1986:57).

His colleague W.K. Tehupeiory was legally classified as European after his return to the Indies, and he started work as a European physician in government service on Bangka (Augustin 1914:3). It can hardly be a coincidence that Bangka was chosen. It seemed that the government wanted to keep 'difficult' cases like Tehupeiory and Asmaoen as far away from Java as possible, in areas where the official hierarchy was less strict than in the centre of the colonial empire. ${ }^{104}$ N.F. Lim, a physician trained in the Netherlands, was the municipal physician in Semarang. When the function of the longest-serving municipal physician on Java became vacant, the position was given to L.J. Eilerts de Haan, although Lim had served longer as municipal physician. ${ }^{105}$ It is likely that Lim's Chinese background affected this choice.

While the government found it awkward to assign native physicians with a Dutch diploma to a 'European' posting in the Civil Medical Service, some native doctors experienced problems with being considered part of the native civil servant corps. For example, a dokter djawa complained in 1895 to a European physician that he was obliged to contribute to the regent's parties and attend them (Bijker et al. 1908: 74). He was not the only one who wanted to distance himself from the native official hierarchy. The government advisor Snouck Hurgronje wrote that dokter djawa sometimes 'give great offence with their deliberate contempt of indigenous forms, their arrogant attitude towards native administrators, their exclusive search for European society while avoiding

${ }_{104}$ But even there highly educated Indonesians were discriminated against. The future professor W. Wertheim described how he was advised in 1930 in the Lampongs, his first station in the Indies, not to make the acquaintance of a native lawyer, who had graduated from Leiden. The latter was not allowed to be a member of the Society in the Lampongs, although in Leiden he had been president of the students' club, Wertheim and Wertheim-Gijse Weenink, 1991:146.

${ }_{105}$ Letter submitted by W.F. Lim, Bulletin van den Bond van Geneesheeren in Ned.-Indië. 14:61-3. W.(F.) must be a typing error, elsewhere he is listed as N.F. Lim or Lim Njat Fa. 
the priyayi's' (Boeka 1904:1007). Some native physicians like J. Wesplat and W.K. Tehupeiory blamed the native heads instead. According to Westplat, some colleagues deliberately withdrew from meetings with native officials for fear of the regents who would make their lives miserable (Augustin 1914:15). Tehupeiory (1909:925) felt that 'the native doctors were often treated improperly by conservative heads' and that 'this example was copied by lesser gods'. According to him, the underlying cause of the friction between the priyayi and the native doctors was the native heads' fear of losing their influence over the population. Because the native doctor was directly subordinate to the European head of the local administration, he was independent of the native head: 'It could give the population the impression the aristocracy had lost their power'. Tehupeiory's analysis is correct: more and more natives were obtaining posts in the native administration because of their education and no longer because of their birth. The power of the priyayi was being challenged and by more people than just the dokter djawa (Van Niel 1960:28-9).

\section{REORGANISATION COMMISSION}

There had long been objections to the fact that the Civil Medical Service and the Military Medical Service were incorporated in one organisation. In reality, the Civil Medical Service was subordinate to the Military Medical Service, which no longer suited colonial policy. The ethical policy promoted being expressly concerned with the health and welfare of the population. In 1906 the Indies government created a commission to prepare a reorganisation of the Civil Medical Service. This Commission had a clear idea of the position of the native doctors. The medical assistance given to the population must in principle be carried out by native doctors. The European civil physicians would ultimately disappear. The native doctors must be able to cure the most common diseases as quickly as possible to limit the loss of labour. Knowledge of these diseases was sufficient to start with; depth and specialisation were concerns for later. Difficult cases would be referred to the hospitals. The native doctors were also useful during epidemics and as mediators between the people and inspectors. Other significant aspects were that they were cheaper than European physicians, knew the language and customs, and could better withstand the effects of the climate and the monotonous life in the 
interior (Bijker et al. 1908:71-2). The Commission did not yet consider the native doctors suitable as supervisors and thus not for the post of adjunct-inspector (Bijker et al. 1908:23).

The Commission formulated not only a vision of the future but also evaluated the current training programme and the graduates. STOVIA was described as a 'half-hearted scientific training programme' and should be condemned as such (Bijker et al. 1908:73). The stricter criteria led to higher drop-out rates, and gave the graduates inflated egos (Bijker et al. 1908:75). The excessive power of the director of the school, who could impose his personal views, would have to be curtailed. The high number of dismissed students could probably be ascribed to his personal sympathies and antipathies. Therefore, a supervisory commission would have to be established (Bijker et al. 1908:83-4).

The Commission had clearly discerned the problematic position of the native doctors: their low salary, the frequent transfers, which always incurred additional expenses and made it impossible to establish a private practice, the offensive situation of unequal pay when taking over duties for the Civil Medical Service; also, the unfair binding agreement prescribed they had to pay back the entire fee if they left government service before the specified interval had expired, regardless of their number of years of service (Bijker et al. 1908:76-8). The Commission could understand why dokter djawa entered private service. In the government service they earned after 20 years the maximum sum of $f 150$ per month, while private companies paid $f 300$ and more. As it was not and should not be STOVIA's aim to provide private companies with cheap doctors, the Commission felt that the government would have to pay them better. What the companies paid was not feasible, but a maximum of $f 250$ after 12 years of service should be possible (Bijker et al. 1908:143).

Despite this insight, the Commission judged that natives were in fact unsuitable for studying science as they had little respect for the truth (Bijker et al. 1908:70). The level of the training programme should be less scientific; the graduates must remain native in their lifestyle, conduct and appearance, and especially their clothing (Bijker et al. 1908:75).

\section{REACTIONS}

On the one hand, the analysis and vision of the future of the reorganisation Commission were well argued, but, on the other, it made un- 
necessarily harmful remarks. The latter led to some emotional reactions such as that of the former director of STOVIA Roll, who crushed these proposals.

When the report from the reorganisation Commission appeared, Roll had just resigned as director of STOVIA and had departed for the Netherlands. He did not agree at all with the concepts and proposals, which would not only have destroyed his life's work but also the future of 'his' boys. He contacted the professors of the University of Amsterdam, who declared that they had had positive experiences with the native doctors who had already obtained the Dutch physician title from them (Roll 1909:14-6). Their response was a major support for Roll. Soetomo would later say that they had wiped the floor with the report (Van der Veur 1987:83). Then Roll published a brochure: Is reorganisatie van de School tot Opleiding van Inlandsche Artsen te Weltevreden nogmaals noodig? (Is reorganisation of the School to Train Native Doctors in Jakarta still needed?). He wrote that it was premature as the reorganisation Commission did not want to wait for the result of the 1900 reforms, but was already proposing new improvements (Roll 1909:13). He fought fiercely against lowering the level of STOVIA. He suspected that C. Winkler prepared these proposals; he had not been able to realise these suggestions as Civil Medical Service inspector but had now grasped the opportunity as member of the Commission (Roll 1909:4). In his brochure Roll did not avoid the confrontation. With his remark that he stood behind the 'awakening Indies', thus supporting the young nationalists and their call for higher education in their own land, he added fuel to the fire (Roll 1909:8).

Nor did the native doctors remain silent. First, W.K. Tehupeiory unambiguously rejected the proposal from the reorganisation Commission to lower the level of education at STOVIA. The Commission proposed that the native doctors would refer difficult cases to a hospital, but did not take into account the transport costs and the fact that an average native would never consider going to a hospital. The native would thus ask for assistance from a dukun, and slowly but surely the European medical aid would become discredited. He concluded with an appeal to the government not to heed the Commission's advice: 'Now that in all corners of the Indies the urge to develop oneself is steadily increasing, now that the government is attempting to meet that need by opening more educational institutes for better qualifications, it cannot be considered sensible to take away the sole institution of middle and higher education 
for the natives in the Indies' (W.K. Tehupeiory 1909:922-8).

Eight native doctors in the Netherlands jointly published a brochure in 1910, Eenige opmerkingen naar aanleiding van de voorstellen tot reorganisatie van den civiel geneeskundigen dienst in Nederl. Oost-Indië (Some remarks in response to proposals to reorganise the Civil Medical Service in the Netherlands East Indies). ${ }^{106}$ Their course of study in the Netherlands allowed them to ascertain that the practical training at STOVIA was better than that in the Netherlands, but the theoretical level needed to be raised. In particular, in the healing of difficult cases, the native doctors could impress the population 'that has little or no faith in European medicine'. They considered several of the Commission's proposals as offensive, such as the one in which the housekeeper of a European civil servant was entitled to free medical care but the second wife of a native civil servant was not, and the proposal to treat Europeans at home but not natives, even though poor Europeans sometimes also lived in the kampong. The supposition that with free choice of doctors irregularities would only be found among natives and not among (Indo-)Europeans, and the idea that only Europeans needed to go on leave while natives did not seemed expressions of discrimination to them. The remark that the native has less respect for the truth than a Westerner angered them: 'The Commission knows nothing of the intimate upbringing in indigenous households; similar virtues are taught there as in European ones; our and their morals do not essentially differ' (Apituley et al. 1910:17-8). They felt medical assistance given by well-trained native doctors was the most sensible manner to introduce European medicine to the population. Finally, they thanked Roll for his efforts on behalf of STOVIA. With their brochure they hoped to influence the discussion in the Lower Chamber with the aim to retain STOVIA just as it was.

The brochure occasionally employs a strong tone; the discriminatory remarks in the reorganisation Commission's report were noted by the authors. This tone is striking for young men at the start of their careers, which could have been harmed by an overly critical attitude of an official body such as the reorganisation Commission. Perhaps their stay in the Netherlands, where they were treated as equals, had made them rather reckless.

\footnotetext{
${ }_{106}$ The authors were the doctors H.J.D. Apituley, R. Tumbelaka and Dr. Abdoel Rivai; the junior doctors H.F. Lumentut and Ph. Laoh and the med. candid. Radjiman, R.M. Brenthel and Moh. Salih.
} 


\section{OUTCOME}

The criticism of the reorganisation Commission's proposal to lower the level of STOVIA and especially the ethical spirit of those days had an effect: the level was preserved, and the medical section was even extended by a year to seven years. Subjects were added to the curriculum: dentistry, ENT, psychiatry (Von Römer 1921:204-5). In addition, a second training programme was established in Surabaya, the Nederlandsch Indische Artsenschool (NIAS, Netherlands Indies Doctor School). Both schools were open to all races and to women. Now that all races were admitted, the title of Inlandsche arts [native doctor] changed to Indische arts [Indies doctor] (De Waart 1926a:54). Thus, the name of the school in Jakarta became School tot opleiding van Indische Artsen [School for training Indies doctors], the abbreviation remained STOVIA. It was also possible to pay tuition to take the course. It can be assumed that admitting girls and non-natives to STOVIA was expected to reduce the shortage of physicians. It does raise the question of why this had not been done earlier. The graduates' salary was considerably increased; from now on the starting salary was $f 150$ and the maximum salary $f 250$ per month (Ind. Stb. 1910 no. 615). In addition, they were permitted to travel second class on the train and were entitled to first-class treatment when admitted to a military hospital (Augustin 1914:3-4). When there were enough native doctors, the intention was to abolish the European civil physician corps and transfer their duties to the natives. Given the increasing need for civil physicians, however, this would not be possible in the short term. ${ }^{107}$ At least one person envisaged a rosy future: 'a Dutch person could be dokter djawa, a native could be European physician'. ${ }^{108}$

The Bond van Geneesheeren responded critically to the Indies government's proposal to create a second medical school in Surabaya and open it to all races. Prosperous Indo-Europeans and Chinese would never dream of letting their children study in the Indies, which would mean that the Surabaya training programme could only attract children of paupers, with a low level of morality and lacking 'almost entirely all good characteristics' required of a physician. Some would make 'a livelihood from abortions and turn adultery into recreation' (Hoofdbestuur 1912:26-

${ }_{107}$ Toelichting begroting 1913, 1912: 3.

108 G.N. 1912. 
8). The reaction of the Bond van Geneesheeren was so offensive that practically the entire European and native press was scandalised, ${ }^{109}$ according to Abdoel Rivai several years later in his speech to the Volksraad (People's Council) (Bosma and Raben 2008:323-4). The members of the Lower Chamber also protested the manner in which the board of the Bond van Geneesheeren had talked about Indo-Europeans. ${ }^{110}$ Others took a different view; they feared that many European children would obtain their medical diploma in the Netherlands after graduating from STOVIA and would settle down there. It was unfair that they obtained their qualification much more easily than the students in the Netherlands and then they were lost to the Indies (Geneeskundige opleiding 1911:11-5). The protests were futile because NIAS started up in 1913.

FEMALE STUDENTS

It is possible that Aletta Jacobs, the first female physician in the Netherlands, influenced the admission of girls to STOVIA. Certainly, during her world tour on 18 April 1912 she met Governor-General A.W.F. Idenburg. Her travel diary reveals that she had argued in favour of admitting girls to the doctor training programme.

Also during the discussion of female doctors for the native women and of hospitals for these women, with exclusively female medical assistance and the training programme for female dokter djawa, His Excellency agreed with our stance much more than many of his officials with whom we had already discussed this issue. Until now, all indigenous girls who applied for the dokter djawa school were rejected, always with one or another excuse, but simply because the powers that be in that department overestimate the difficulty of teaching medicine together with young

109 Among others, the chief editor of the Favabode (Misplaatste zelfverheffing, 10-10-1912) (Misplaced selfimportance), who referred to a reaction in Het Bataviasch Nieuresblad; also Keuchenius 1912 referred to it. ${ }_{110}$ They were J.G. Scheurer, former missionary physician in Yogyakarta, and W.H. Bogaardt, Handelingen TK 1912-3, respectively, in the meeting of 28-11-1912, 912 and in that of 29-11-1912, 929. In the Nieuwes van den Dag voor Nederlandsch-Indië of 30-10-1912, the secretary of the Bond van geneesheeren 'rectified' this. The Bond had only meant that a physician's diploma in the hands of 'those originating from the lowest classes of the European society, belonging as it were to the fringes of this society, would present a danger to this colony', cited by Bogaardt. Minister of Colonies De Waal Malefijt said in response that he intended to issue his disapproval of the Bond's statements about Indo-Europeans. After this rectification, this was no longer necessary, Handelingen TK 1912-3, meeting of 2-12-1912, 978. 


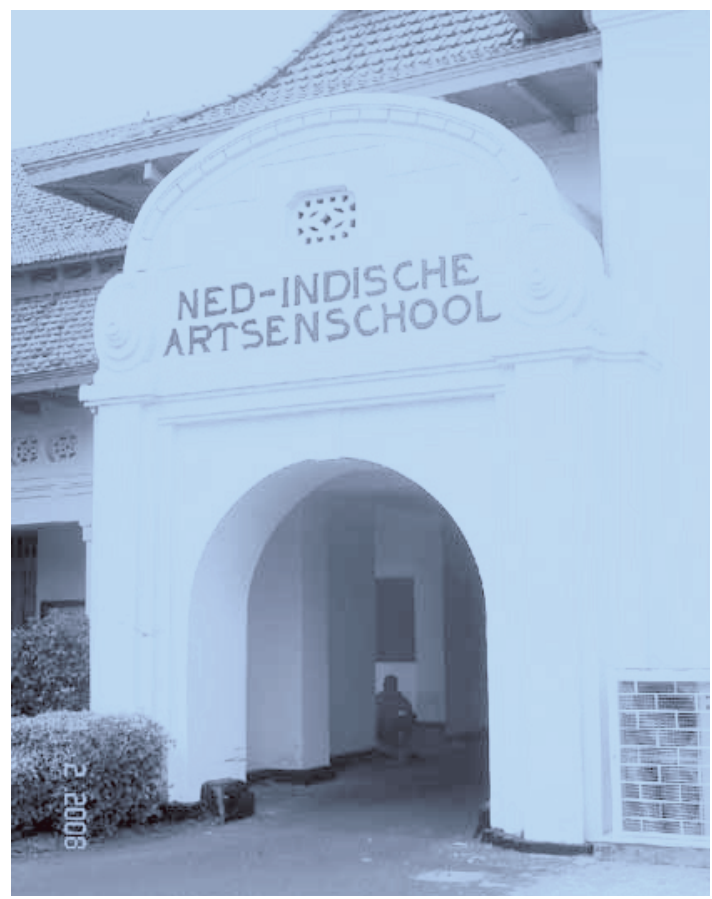

NIAS, now the Faculty of Medicine of Airlangga University (photo J.H. Peters)]

men and do not sufficiently realise the desirability of having female doctors for the native women. (Jacobs 1913:425.)

While girls were indeed admitted from then on, they were not eligible for employment in the Civil Medical Service. They thus had to pay for their training programme themselves and arrange their own accommodations. A study fund was established to support them, the Vereeniging tot Vorming van een Studiefonds voor Opleiding van Vrouwelijke Inlandsche Artsen (Society to form a study fund for training female native doctors). ${ }^{111}$ The applications for STOVIA from young women got

11 Established by Charlotte Jacobs, the sister of Aletta Jacobs and apothecary in Batavia, the writer Marie Kooij-van Zeggelen and Elisabeth van Deventer-Maas, the wife of the MP and author of 'Een eereschuld'. The fund was also meant to support the training of nurses. In her will, Charlotte Jacobs specified that the study fund would receive the usufruct of $f$ 2000, De Wilde 2000:193. 


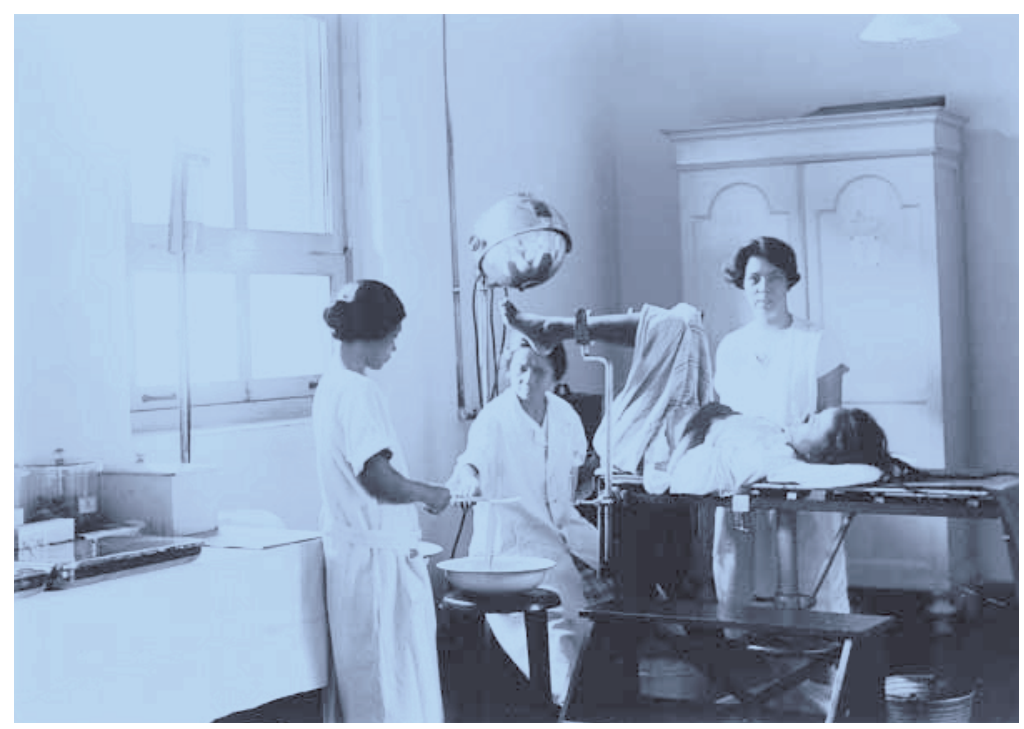

Marie Thomas (second from left) in the women's hospital, in 1929 (photo collection museum Boerhaave, Leiden)

off to a slow start. In September 1912 the first female student, Marie Thomas, was admitted and two years later the second, Anna Warouw. Both came from the Minahasa. Marie Thomas would later become the first Indonesian specialist in gynaecology and obstetrics (Barten and Stolk 1987:222).

DRAWING UP THE BALANCE

To obtain insight into the results of the training programme, we have several sources available: the Colonial Reports, the report of the reorganisation Commission, the report on STOVIA for the 1904-1905 academic year, the first Almanac from STOVIA and the retrospective by A. de Waart, director of STOVIA, in the jubilee book for the years 18511926. Different numbers of students and graduates are listed. In addition, not everyone used the same systematics, and some changed their method of notation in the course of the 1875-1915 period (per academic year or per calendar year; including or excluding the dokter djawa who be- 
came vaccinators). It is therefore impossible to find unambiguous figures.

According to the report on STOVIA for the 1904-1905 academic year, 725 students were accepted for the 31 courses in the period 1875 through 1905, on average 23 students per academic year. At the time of publication, 119 of them were still at the school, and of the remaining 606 students, only 156 had graduated, not even 26\% (Jaarlijksch verslag STOVIA 1906:appendix 12). The premature drop-out (about 75\%) was much higher in this period than in the previous one: in the 1851-1875 period, it amounted to $42 \%$.

In his retrospective, A. de Waart reported the following figures: before 1890 only $10 \%$ graduated with a diploma, on average 5 per year. Because after that only applicants from the European primary school were admitted, $40 \%$ reached the finish line. After introducing the admissions exam in 1903 and the reorganisation of the course in 1902, 48.8\% graduated (De Waart 1919: 91, 1926a:30-2). As director of STOVIA, A. de Waart may have painted matters in a rosy light, but even he admitted that despite the improvements, not even half of the students passed their final exam.

When contemplating these sad figures, we must remember that increasingly more graduates entered private employment. Of the 185 graduates in 1915, 125 were in government service and 60 in private service. The latter number was probably higher in reality because the government did not receive statements from all private companies. The reorganisation Commission's rather unusual complaint for the tropics that the native doctors would disappear like snow in the sun proved correct (Bijker et al. 1908:75).

\section{ONCLUDING REMARKS}

The dokter djawa school was established to replace the dukun by Westerntrained, native doctors. It took until 1875 before people were convinced of the utility of well-trained native doctors for the Medical Service, and from then on the investments in the training programme were increased with some regularity. As its level rose, the graduates could be given more tasks. At first, the dokter djawa worked primarily as assistants to European physicians, but gradually they took over their tasks. The government employed them increasingly often as intermediaries between Western health care and the population. Some native doctors assumed this task volun- 
tarily. The working conditions were much worse than those for other native officials, resulting in a growing flood leaving government service. The imposition of a binding agreement was a vain attempt to put a halt to this. Ultimately, the government trained more and more native doctors for the free market (the business community and independent practice) and fewer for its 'own' Civil Medical Service.

The ethical policy stipulated formally for the first time that the Netherlands had a responsibility to provide health care for the population. Because of this policy and the opening up of the Indies to business, increasing numbers of physicians were required, both by the government and by private companies. As this need could not be met, there was a continuous shortage. STOVIA was one of the rare possibilities for higher education for natives. It offered, along with a medical training programme, a possibility for emancipation, which suited the ethicists' philosophy well. The former director of Education, Religion and Industry, the ethicist Abendanon, considered STOVIA an acrostic of the words Stuwkracht Tot Ontwikkeling Van Aanleg (Stimulus to encourage development of potential). ${ }^{112}$ The first STOVIA graduates who studied in Amsterdam confirmed the ethicists in their ideals. They assimilated completely with the Dutch: they were members of the Amsterdam students' union, got involved in various discussions about the design of the Civil Medical Service and married Dutch women. Through their years of residence at STOVIA, they grew used to a European environment. They furnished their houses in European style, they felt a need for European reading matter and music, and sent their children to European schools. ${ }^{13}$ After W.K. Tehupeiory (1908:121) had given his lecture to the general meeting of the Indies Society in 1908, C.Th. van Deventer rejoiced that 'the spiritual evolution among the native population in the Netherlands Indies $[\ldots]$ is not only well underway, it has advanced considerably to a certain end. [...] [1]ts appearance must be the fruit of increasing civilisation'. Tehupeiory's lecture must have been proof for the ethicists that they were right.

\footnotetext{
112 Orgaan van Indische Artsen 1919, no. 2:VII. Abendanon spoke the words during a meeting of the Indies Society in the Netherlands; the board of the Society of Native Physicians quoted him in their Orgaan. Abendanon used the term 'acrostic' rather loosely, as it refers to a poem in which certain, mostly the first, letters of each line or stanza form a word,.

113 W.K. Tehupeiory 1908:115. I would like to thank here the late A. Visser who granted me access to his mother-in-law's letters, E.M. Lumentut-Keller. She was married to H.F. Lumentut, who was among the first group of Stovians who obtained their Dutch diploma in Amsterdam.
} 
As usual with an emancipation there were also tensions, for the native doctors, for the native elite, for the government and for the European colleagues. The native doctors lived between two worlds. This was evident in their clothing. Originally, the government insisted that the dokter djawa wear native clothing to show that he, just like his patients, was part of indigenous society. In this vision, the dokter djawa was attached to carrying the payung, which was only allowed in 1882. Over time the native doctors, just like other natives with a Western education, wanted to wear Western clothing, which was permitted around 1900. The priyayi had a difficult relationship with native doctors because they were not part of the native official hierarchy but belonged to the Civil Medical Service, which was part of the European official structure. Many European administrators also did not know how to deal with the dokter djawa. They were natives but with Western educations, and they spoke fluent Dutch. In the beginning the dokter djawa assisted the European physicians, and some of the latter abused their power by making the dokter djawa do their work and by pocketing the allowances themselves. This caused tension. Over time the European physicians' tasks were transferred to their native colleagues. Many European physicians continued to feel that natives were incapable of working independently as doctors. The high level of education and the impossibility of working as a respected doctor led to STOVIA becoming a breeding ground for nationalism. 